\title{
Ocean resurge-induced impact melt dynamics on the peak-ring of the Chicxulub impact structure, Mexico
}

\author{
Felix M. Schulte ${ }^{1}$ Axel Wittmann ${ }^{2}$. Stefan Jung ${ }^{3} \cdot$ Joanna V. Morgan ${ }^{4} \cdot$ Sean P. S. Gulick ${ }^{5,6} \cdot$ David A. Kring $^{7}$. \\ Richard A. F. Grieve ${ }^{8,9} \cdot$ Gordon R. Osinski ${ }^{8,9} \cdot$ Ulrich Riller ${ }^{1}$ (D) IODP-ICDP Expedition 364 Science Party
}

Received: 21 June 2020 / Accepted: 14 February 2021 / Published online: 18 March 2021

(C) The Author(s) 2021

\begin{abstract}
Core from Hole M0077 from IODP/ICDP Expedition 364 provides unprecedented evidence for the physical processes in effect during the interaction of impact melt with rock-debris-laden seawater, following a large meteorite impact into waters of the Yucatán shelf. Evidence for this interaction is based on petrographic, microstructural and chemical examination of the 46.37-m-thick impact melt rock sequence, which overlies shocked granitoid target rock of the peak ring of the Chicxulub impact structure. The melt rock sequence consists of two visually distinct phases, one is black and the other is green in colour. The black phase is aphanitic and trachyandesitic in composition and similar to melt rock from other sites within the impact structure. The green phase consists chiefly of clay minerals and sparitic calcite, which likely formed from a solidified water-rock debris mixture under hydrothermal conditions. We suggest that the layering and internal structure of the melt rock sequence resulted from a single process, i.e., violent contact of initially superheated silicate impact melt with the ocean resurge-induced water-rock mixture overriding the impact melt. Differences in density, temperature, viscosity, and velocity of this mixture and impact melt triggered Kelvin-Helmholtz and Rayleigh-Taylor instabilities at their phase boundary. As a consequence, shearing at the boundary perturbed and, thus, mingled both immiscible phases, and was accompanied by phreatomagmatic processes. These processes led to the brecciation at the top of the impact melt rock sequence. Quenching of this breccia by the seawater prevented reworking of the solidified breccia layers upon subsequent deposition of suevite. Solid-state deformation, notably in the uppermost brecciated impact melt rock layers, attests to long-term gravitational settling of the peak ring.
\end{abstract}

Keywords Impact cratering $\cdot$ Impact melt rock $\cdot$ Peak ring $\cdot$ Ocean resurge $\cdot$ Chicxulub

\section{Introduction}

The members of IODP-ICDP Expedition 364 Science Party are listed in acknowledgements.

\section{Ulrich Riller}

ulrich.riller@uni-hamburg.de

1 Institut Für Geologie, Universität Hamburg, Bundesstraße 55, 20146 Hamburg, Germany

2 Eyring Materials Center, Arizona State University, Arizona, USA

3 Mineralogisch-Petrographisches Institut, Universität Hamburg, Grindelallee 48, 20146 Hamburg, Germany

4 Department of Earth Science and Engineering, Imperial College London, London SW7 2AZ, UK
Deposits of impact melt, at times continuous sheets, covering crater floors are known from a number of impact structures on Earth and are paramount for elucidating hypervelocity impact processes (Grieve 1975; Grieve et al. 1977;

5 Institute of Geophysics and Department of Geological Sciences, University of Texas at Austin, Austin, TX 78758, USA

6 Center for Planetary Systems Habitability, University of Texas at Austin, Austin, TX 78712, USA

7 Lunar and Planetary Institute, Houston, TX 77058, USA

8 Department of Earth Sciences, University of Western Ontario, London, ON N6A 5B7, Canada

9 Institute for Earth and Space Exploration, University of Western Ontario, London, ON N6A 5B7, Canada 
Floran et al. 1978; Onorato et al. 1978; Kring and Boynton 1992; Therriault et al. 2002). Impact melt deposits differ significantly in volume, composition and stratigraphy in different craters. These differences are generally attributed to target rock type, cratering dynamics and impact parameters, such as mass, velocity and incidence angle of the projectile (Grieve and Cintala 1992; Pierazzo et al. 1997; Pierazzo and Melosh 1999; Grieve et al. 2006; Collins et al. 2020). International Ocean Discovery Program (IODP)-International Continental Scientific Drilling Program (ICDP) Expedition 364 drilled into the topographic peak ring of the Chicxulub impact structure, Mexico (Fig. 1). The recovered core included an 46-m-thick, impact melt rock sequence overlying shocked granitoid basement rock and is covered, in turn, by impact melt-bearing breccia, which is logged as suevite, and post-impact passive continental margin strata (Fig. 2a) (Morgan et al. 2016, 2017). Thus, the drill core provides, for the first time, the opportunity to study the emplacement of impact melt rock covering the Chicxulub peak ring, which formed in a shelf-to-slope depth marine setting (Gulick et al. 2008, 2019; Osinski et al. 2020).

As a consequence of its position on top of the peak ring, likely filling a subtle topographic depression (Gulick et al. 2019), the impact melt rock sequence is relatively thin. Nonetheless, its distinct compositional and structural differences allowed us to divide the 46.37-m-thick sequence into four units-from bottom to top: $3 \mathrm{~B}, 3 \mathrm{~A}$, $2 \mathrm{C}-2$ and $2 \mathrm{C}-1$ (Fig. 2b), which may extend across the peak ring, based on imaging of the suevitic unit as a lowvelocity zone in full-waveform inversions (Morgan et al. 2011; Christeson et al. 2018). The units consist chiefly of a black silicate melt rock phase and a green carbonate-bearing phase, both hosting shocked target rock fragments (Morgan et al. 2017; Slivicki et al. 2019). We provide petrographic, microstructural and chemical analyses of both phases, collectively based on the examination of the drill core and line scan images, polarization and scanning electron microscopy, as well as electron microprobe analyses. Notably, we investigate the cause for the layering of the petrographically and structurally complex impact melt rock sequence, as well as the possible origin of the green carbonate-bearing phase. Our study leads us directly to elucidating the violent processes of melt-water-rock interaction (MWI) brought about by the contact of initially superheated impact melt with resurge-generated water-rock masses after crater formation. Consequently,

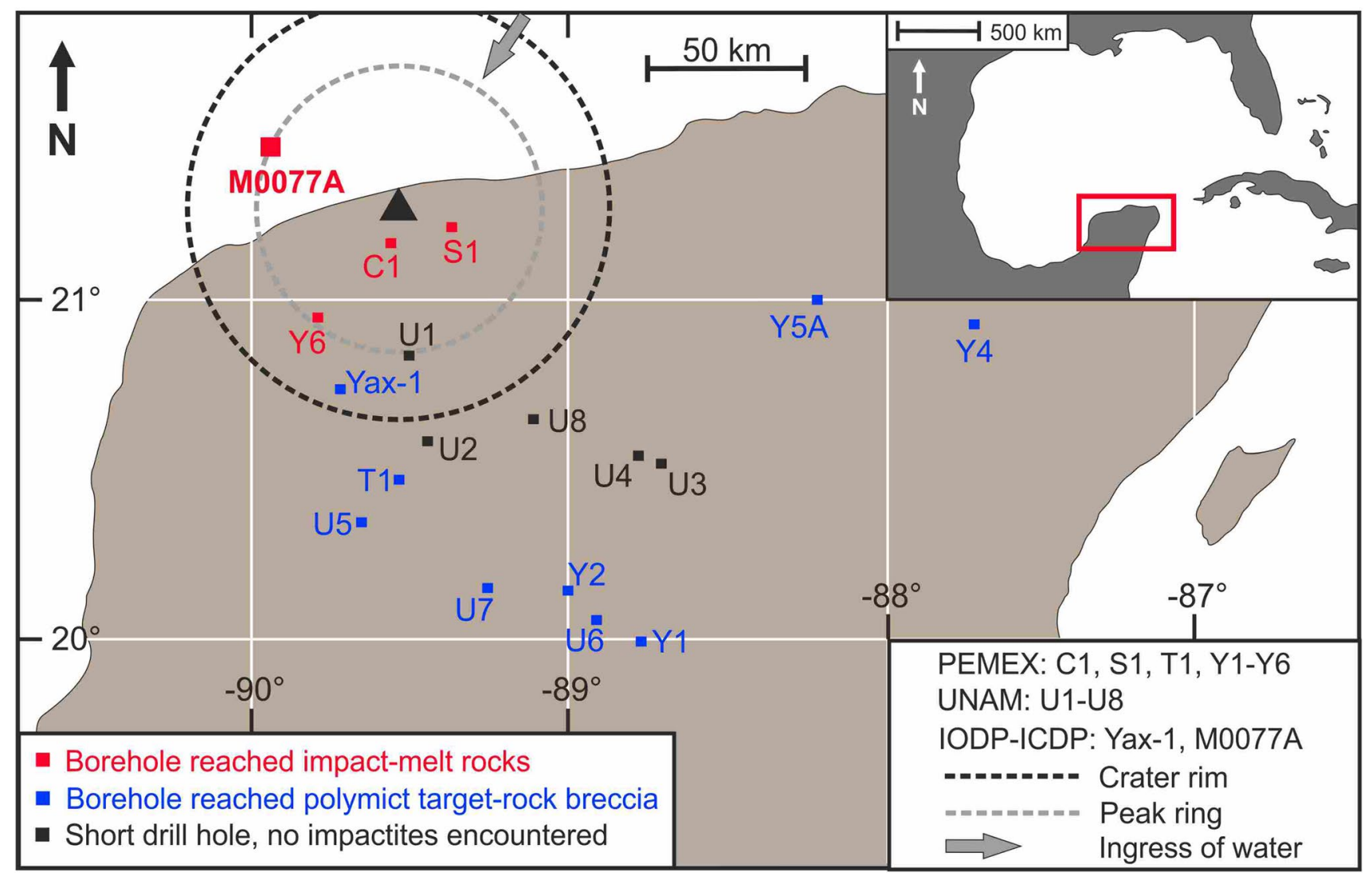

Fig. 1 Map showing the trace of the peak ring (grey dotted line) and the innermost crater rim (black dotted line) of the Chicxulub impact structure, Yucatán peninsula, Mexico, and locations of other drill sites (modified from Rebolledo-Vieyra and Urrutia-Fucugauchi (2004) 

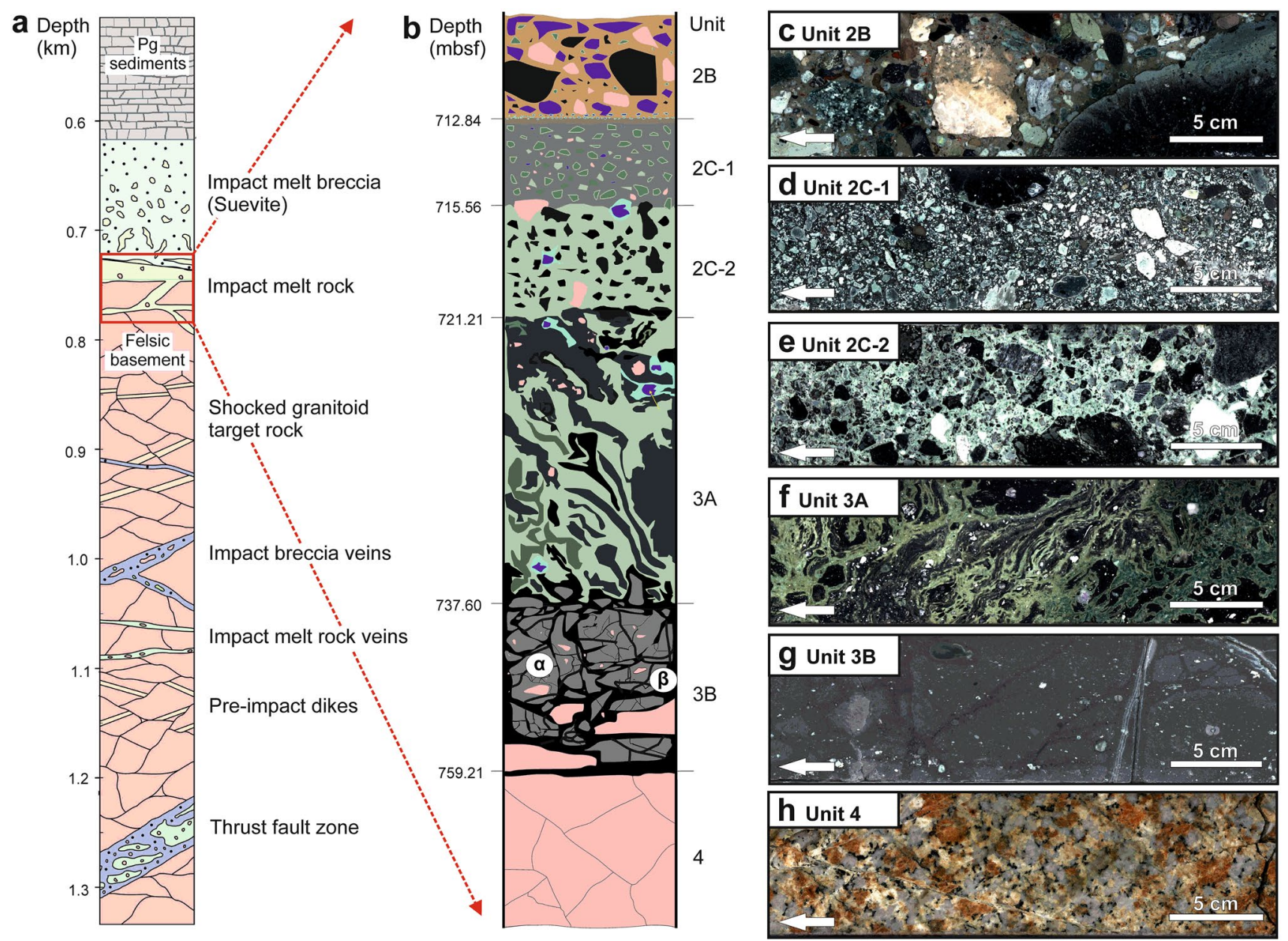

Fig. 2 Stratigraphy of impactites and post-impact sedimentary rocks of drill core M0077. a Lithology of the entire drill core modified from Morgan et al. (2016). b Schematic diagram depicting the major lithological and structural characteristics of the individual units of the impact melt rock sequence on top of unit 4 shocked granitoid target rock and covered by unit 2B suevite. Fragments of carbonate rock (dark blue) are enveloped by flow-textured polycrystalline carbonate schlieren (light blue). $\mathbf{c}-\mathbf{h}$ Representative line-scan images of $\mathbf{c}$ unit $2 \mathrm{~B}$ suevite, $\mathbf{d}$ unit $2 \mathrm{C}-1$ impact melt rock breccia character-

our study has important ramifications for the dynamics of impact melt systems exposed to large volumes of water.

\section{The Chicxulub impact structure}

Knowledge on the Chicxulub impact structure is limited, as the structure is buried under hundreds of meters of postimpact carbonate, sandstone and evaporite strata (Lopez Ramos 1975). With a diameter of approximately $200 \mathrm{~km}$, the impact structure is the third largest known on Earth (Grieve and Therriault 2000; Grieve et al. 2008). Compared to the two largest known impact structures, Sudbury, Canada, and Vredefort, South Africa, which are Paleoproterozoic in age, ized by angular silicate melt rock (dark) and green carbonate-bearing fragments with resorbed margins set in a carbonate matrix, e unit 2C-2 impact melt rock breccia showing mostly angular silicate melt rock fragments in a green melt rock matrix, $\mathbf{f}$ unit $3 \mathrm{~A}$ flow-textured impact-melt rock displaying convoluted layers of black and green silicate melt rock phase, $\mathbf{g}$ unit 3B silicate impact melt rock, with melt rock phases $\alpha$ and $\beta$, displaying mottled texture with jigsaw geometry of hydrothermally altered fractures and $\mathbf{h}$ unit 4 shocked granitoid target rock

the $66 \mathrm{Ma}$ Chicxulub is substantially younger (Swisher et al. 1992; Schulte et al. 2010). Therefore, and due to the near absence of post-impact tectonic modification (Riller et al. 2018), the Chicxulub is, besides Popigai, Russia (Masaitis et al. 2005), the best preserved peak-ring basin on Earth replete with a peak ring (Morgan et al. 1997, 2000; Gulick et al. 2008). Only at its northeastern margin, where the peak ring and the crater walls straddle the continental slope of the Yucatan shelf, does the Chicxulub impact structure appear to be morphologically dissected (Hildebrand et al. 1998; Collins et al. 2008; Gulick et al. 2008).

Geological information on the Chicxulub impact structure is based on limited industry and scientific drilling (Fig. 1), geophysical studies, and analysis of its ejecta deposits. Thus, 
knowledge on the formation, shape and extent of its impact melt rocks, estimated at $\sim 10^{4} \mathrm{~km}^{3}$ (Grieve and Cintala 1992; Barton et al. 2010), is sparse. For example, it is unknown to what extent impact melt rocks cover the crater floor. Seismic profiles (Vermeesch and Morgan 2004, 2008) seem to indicate that the coherent impact melt sheet is largely limited to a lens within the interior of the peak ring (Gulick et al. 2013), $65 \mathrm{~km}$ in diameter and 2.2-4.4 km thick (Barton et al. 2010).

Industry drilling at three sites prior to Expedition 364 sampled the impact melt rocks of the Chicxulub impact structure (Fig. 1). These rocks have an andesitic composition and are overlain by suevite (Hildebrand et al. 1991; Kring and Boynton 1992; Sharpton et al. 1992). To date, analyses of impact melt rock are based on rather small samples of glassy rocks, containing mainly feldspar and pyroxene (Hildebrand et al. 1991; Kring and Boynton 1992; Sharpton et al. 1992; Swisher et al. 1992; Schuraytz et al. 1994). Other studies focused on age determination (Hildebrand et al. 1991; Sharpton et al. 1992; Swisher et al. 1992; Kring 1993) and on the relationship between the impact melt rocks and (Haitian) tektites embedded in the K-Pg boundary layer in terms of age, geochemical and petrological character (Swisher et al. 1992; Kring and Boynton 1992). Results of these studies are consistent with previous hypotheses that the environmental effects of a large impact event terminated the Cretaceous period (Alvarez et al. 1980; Smit and Hertogen 1980), and with Chicxulub being the K-Pg impact (Schulte et al. 2010; Renne et al. 2013).

\section{Background information on impact melt rocks}

Impact melting is a consequence of thermodynamically irreversible shock compression introducing internal energy into the shocked material. Upon adiabatic pressure release, a portion of this energy remains as heat and can lead to a change in the physical state of the material into melt or vapor (Melosh 1989; Osinski et al. 2018). Thus, impact melting is an extremely rapid process and affects any lithology capable of storing sufficient internal energy after shock compression. Due to the highly dynamic nature of impact cratering, impact melt assimilates, and turbulently mixes with, target rock fragments (Grieve et al. 1977; Floran et al. 1978). Immediately after the passing of the shock wave, the impact melt is superheated and, in large craters, forms a coherent sheet that ponds in the crater during crater modification. In many cases, the melt is thought to be chemically homogeneous prior to cooling to the liquidus temperature and may maintain this homogeneity, if solidification is rapid enough to prevent the melt from differentiating (Floran et al. 1976, 1978; Grieve et al. 1976; Phinney and Simonds 1977; Zieg and Marsh 2005). In this case, impact melt rock will lack any petrographic layering.

Previous studies of terrestrial craters indicate that the impact melt volume increases with impact energy (Dence 1971). The cooling rate of an impact melt sheet depends on its thickness (Onorato et al. 1978), which, in turn scales as a power law with increasing crater diameter (Grieve and Cintala 1992; Grieve et al. 2006). Therefore, craters larger than $90 \mathrm{~km}$ in diameter on Earth host melt sheets that are thick enough to chemically differentiate (Therriault et al. 2002; Spray et al. 2010). The most prominent terrestrial example of a layered silicate melt rock sheet is the $~ 3.5-\mathrm{km}$ thick Main Mass of the 1.85 Ga Sudbury Igneous Complex (SIC) of the Sudbury impact structure, Canada (Grieve et al. 1991; Deutsch et al. 1995; Lightfoot et al. 1997). The SIC is made up chiefly by four petrographically distinct layers, which from bottom to top are known as the Norite, the Quartz Gabbro, the Granophyre, and the Upper Contact Unit layers (Naldrett and Hewins 1984; Grieve et al. 1991; Lightfoot et al. 1997; Ivanov and Deutsch 1999; Anders et al. 2015). Mechanisms proposed to explain the layering of the SIC include fractional crystallization (Grieve et al. 1991; Therriault et al. 2002; Latypov et al. 2019), density stratification through variation in clast population (Golightly 1994) and liquid immiscibility of compositionally different impact melts (Zieg and Marsh 2005). Due to the similar size and crystalline target rock composition of the Sudbury and the Chicxulub impact structures (Grieve et al. 1991, 2008; Barton et al. 2010), impact melt rocks of both may resemble each other (Kring 1997).

Impact melt rocks can vary in terms of texture, which depends chiefly on target rock type and cooling rate (Floran et al. 1978). For example, impact on igneous and metamorphic silicate rocks forms impact melt, which has the capacity to assimilate large volumes of their target fragments (Grieve 1975). By contrast, impact melt rocks evolving from sedimentary targets show large amounts of fragments (Osinski et al. 2005), which enhance cooling rates of melt sheets, resulting in aphanitic to glassy melt rock (Kieffer and Simonds 1980; Osinski et al. 2008a). In the terrestrial environment, the proportion of pre-impact sedimentary cover rock with respect to crystalline basement rock decreases with impact magnitude in the terrestrial environment. Thus, impact melt rock in large impact structures, such as Chicxulub, formed chiefly from basement rock ( $\geq 90 \%$ : Kring and Boynton 1992; Barton et al. 2010; Huber et al. 2020).

Suevite from specific impact structures can differ markedly in terms of the proportion of impact melt, and the shape and petrographic character of the shocked target rock fragments (Stöffler and Grieve 1994, 2007; Stöffler et al. 2018). The differences are due to target rock type, impact energy, and whether impact occurred in a marine or continental setting (Grieve et al. 2010; Meyer et al. 2011; Stöffler et al. 
2013; Osinski et al. 2016, 2020). In contrast to some authors relating the term "suevite" to multiple formation processes (e.g., Grieve et al. 2010; Osinski et al. 2016, 2020), we use the term, here, in only a generic sense to describe a polymict, allochthonous impact melt-bearing breccia.

\section{Methods}

Based on detailed investigations of the drill core and respective line scan images using the software CoreWall-Corelyzer, 26 polished thin sections (Table 1) with a thickness of ca. $30 \mu \mathrm{m}$ were analysed using a Zeiss Axio Scope.A1 polarising microscope for petrographic and microstructural characterization. An AxioCam MRc Rev.3 FireWire and
Canon 1300D camera attached to the microscope was used to generate high-resolution digital images. Fine-grained mineral aggregates, detected in thin section, were examined with a Zeiss Leo VP 1455 scanning electron microscope (SEM-EDX) at the Institute of Geology of Universität Hamburg.

In addition, a Cameca SX100 electron microprobe (EMP-WDX), hosted at the Institute of Mineralogy and Petrography at Universität Hamburg, was used to acquire chemical compositions of selected mineral phases, as well as backscattered electron images and element maps. The microprobe operated at an accelerating voltage of $15 \mathrm{kV}$, a beam current of $20 \mathrm{nA}$ and a beam diameter of $0 \mu \mathrm{m}$ to measure single feldspars, and a beam diameter of $10 \mu \mathrm{m}$ to measure the composition of the impact melt. The counting

Table 1 Drill core samples from which polished thin sections were manufactured for petrographic analysis. MBSF indicates meters below sea floor

\begin{tabular}{|c|c|c|c|c|c|c|c|c|c|c|c|}
\hline Depth (mbsf) & Sample & Unit & Expedition & Site & Hole & Core & Core type & Section & Section half & Top depth & Bottom depth \\
\hline 712.84 & FS94 & $2 \mathrm{C}-1$ & 364 & 77 & A & 83 & $\mathrm{R}$ & 1 & $\mathrm{~W}$ & 76.00 & 80.50 \\
\hline 712.885 & FS95 & & 364 & 77 & A & 83 & $\mathrm{R}$ & 1 & W & 80.50 & 84.00 \\
\hline 712.99 & FS68-1 & & 364 & 77 & A & 83 & $\mathrm{R}$ & 1 & W & 91.00 & 94.00 \\
\hline 712.99 & FS68-2 & & 364 & 77 & A & 83 & $\mathrm{R}$ & 1 & W & 91.00 & 94.00 \\
\hline 713.73 & FS96 & & 364 & 77 & A & 84 & $\mathrm{R}$ & 2 & W & 19.00 & 21.50 \\
\hline 714.13 & FS97 & & 364 & 77 & A & 84 & $\mathrm{R}$ & 2 & W & 59.00 & 62.00 \\
\hline 714.82 & FS67 & & 364 & 77 & A & 84 & $\mathrm{R}$ & 3 & W & 0.00 & 3.00 \\
\hline 717.985 & FS98 & $2 \mathrm{C}-2$ & 364 & 77 & A & 86 & $\mathrm{R}$ & 1 & W & 34.50 & 38.00 \\
\hline 719.07 & FS99 & & 364 & 77 & A & 86 & $\mathrm{R}$ & 2 & W & 20.00 & 21.50 \\
\hline 719.33 & FS66 & & 364 & 77 & A & 86 & $\mathrm{R}$ & 2 & W & 46.00 & 48.50 \\
\hline 719.96 & FS100 & & 364 & 77 & A & 87 & $\mathrm{R}$ & 1 & W & 42.00 & 46.00 \\
\hline 720.72 & FS65-1 & & 364 & 77 & A & 87 & $\mathrm{R}$ & 2 & W & 0.00 & 3.00 \\
\hline 720.72 & FS65-2 & & 364 & 77 & A & 87 & $\mathrm{R}$ & 2 & W & 0.00 & 3.00 \\
\hline 721.21 & FS101a & $3 \mathrm{~A}$ & 364 & 77 & A & 87 & $\mathrm{R}$ & 2 & W & 49.00 & 63.00 \\
\hline 721.21 & FS101b & & 364 & 77 & A & 87 & $\mathrm{R}$ & 2 & W & 49.00 & 63.00 \\
\hline 722.76 & FS64 & & 364 & 77 & A & 88 & $\mathrm{R}$ & 1 & W & 17.00 & 20.00 \\
\hline 722.76 & FS64-3 & & 364 & 77 & A & 88 & $\mathrm{R}$ & 1 & W & 17.00 & 20.00 \\
\hline 723.5 & FS63 & & 364 & 77 & A & 88 & $\mathrm{R}$ & 1 & W & 91.00 & 94.00 \\
\hline 727.275 & FS102 & & 364 & 77 & A & 89 & $\mathrm{R}$ & 2 & W & 40.50 & 42.00 \\
\hline 731.08 & FS62 & & 364 & 77 & A & 90 & $\mathrm{R}$ & 3 & W & 5.00 & 7.00 \\
\hline 734.93 & FS61 & & 364 & 77 & A & 92 & $\mathrm{R}$ & 1 & W & 14.00 & 16.00 \\
\hline 737.3 & FS103 & & 364 & 77 & A & 92 & $\mathrm{R}$ & 2 & W & 109.00 & 110.00 \\
\hline 737.3 & FS103x & & 364 & 77 & A & 92 & $\mathrm{R}$ & 2 & W & 109.00 & 110.00 \\
\hline 741.17 & FS104 & $3 B$ & 364 & 77 & A & 94 & $\mathrm{R}$ & 1 & W & 28.00 & 31.50 \\
\hline 742.23 & FS60 & & 364 & 77 & A & 94 & $\mathrm{R}$ & 2 & W & 21.00 & 23.00 \\
\hline 743.575 & FS105 & & 364 & 77 & A & 94 & $\mathrm{R}$ & 3 & W & 38.50 & 41.00 \\
\hline 745.24 & FS59 & & 364 & 77 & A & 95 & $\mathrm{R}$ & 2 & W & 36.00 & 38.00 \\
\hline 749.51 & FS109 & & 364 & 77 & A & 96 & $\mathrm{R}$ & 3 & W & 0.00 & 2.50 \\
\hline 754.72 & FS106 & & 364 & 77 & A & 98 & $\mathrm{R}$ & 2 & W & 42.00 & 45.00 \\
\hline 757.8 & FS107 & & 364 & 77 & A & 100 & $\mathrm{R}$ & 1 & W & 79.00 & 81.00 \\
\hline 758.12 & FS108 & & 364 & 77 & A & 100 & $\mathrm{R}$ & 2 & W & 0.00 & 3.00 \\
\hline 758.12 & FS108x & & 364 & 77 & A & 100 & $\mathrm{R}$ & 2 & W & 0.00 & 3.00 \\
\hline
\end{tabular}


times were $20 \mathrm{~s}$ for peak and $10 \mathrm{~s}$ for the background signal. Before quantitative analysis, all elements were standardized on matrix-matched natural and synthetic reference materials. The phi-rho- $z$ correction was applied to all data and uncertainties on major oxide concentrations are in the range of $1-2 \%$ relative. To monitor accuracy and precision over the course of this study, microanalytical reference materials were analysed and obtained results match published values within error.

\section{Results}

\section{Petrography and structure of impact melt rocks}

Initially, impact melt rock recovered at Site M0077 of IODPICDP Expedition 364 was divided into two units (Morgan et al. 2017), which are from bottom to top: units $3 \mathrm{~B}$ and $3 \mathrm{~A}$, and the overlying unit 2 , with sub-units $2 \mathrm{C}, 2 \mathrm{~B}$, and $2 \mathrm{~A}$ interpreted as suevite (Fig. 2b). However, the physical properties of unit $2 \mathrm{C}$ align better with the impact melt rock units $3 \mathrm{~B}$ and $3 \mathrm{~A}$ than the suevite units $2 \mathrm{~B}$ and $2 \mathrm{~A}$ (Christeson et al. 2018), which prompted Gulick et al. (2019) to term unit $2 \mathrm{C}$ a melt rock breccia. Alternatively, unit $2 \mathrm{C}$ could be termed a clast-rich impact melt rock in keeping with the IUGS impact lithology classification scheme (Stöffler and Grieve 2007).

Based on distinct petrographic, structural and chemical characteristics, we subdivide unit $2 \mathrm{C}$ into units $2 \mathrm{C}-2$ and 2C-1 (Fig. 2b). The boundaries between the individual units of the impact melt rock sequence are gradational over distances of a few centimetres to about a decimetre. By contrast, the lower and the upper contacts of the impact melt rock sequence with shocked granitoid target rock (Figs. 2h, 3f) and suevite (Figs. 2c, 3a), respectively, are well defined and discordant.

Unit 3B is $21.61 \mathrm{~m}$ thick and composed of black silicate melt rock, hosting one large granitoid target rock fragment at its base (Fig. 2b, g). Macroscopically, the melt rock appears petrographically homogeneous and displays a mottled texture with jigsaw fracture geometry (Figs. 2g, 3e), evident by two silicate phases, labelled $\alpha$ and $\beta$ in Figs. 2b, $3 \mathrm{e}, 4 \mathrm{a}, 5 \mathrm{a}$ and $6 \mathrm{a}$. The melt rock is chiefly composed of up to 80 - $\mu \mathrm{m}$-long acicular plagioclase (Fig. 4a) and subordinate amounts of clay minerals and opaque minerals. Plagioclase is hyalopilitic and its margins display pilotaxitic growth. Except for the occasional crystal fragments and elongate vesicles, filled with sparitic calcite (Fig. 4b), the melt rock is devoid of inclusions (Fig. 4a). Fractures in the melt rock are filled with sparitic calcite and sporadically with phyllosilicates. Fracture margins consist of alkali feldspar and opaque residual material (Fig. 4a).
Unit $3 \mathrm{~A}$ is $16.39 \mathrm{~m}$ thick and consists of a black silicate melt rock phase-similar to that in unit 3B-intermingled with a green phase, collectively forming schlieren (Figs. 2b, f, 3d). The green phase consists of $\sim 60 \%$ sheet silicates, $\sim 25 \%$ calcite and $\sim 15 \%$ garnet and opaque minerals (Slivicki et al. 2019) and sporadic fluorite. Calcite is sparitic, with amoeboid and interlobate grain boundaries (Fig. 4c). Calcite grain size decreases toward the phase boundaries, which host some andradite garnet (Fig. 5b) and pyroxene, and are enriched in clay minerals (Fig. 4c). Similar to unit $3 \mathrm{~B}$, black silicate melt rock of unit $3 \mathrm{~A}$ consists mostly of microcrystalline feldspar and sporadically of phyllosilicate and opaque minerals (Fig. 5b).

Unit $2 \mathrm{C}-2$ is $5.65 \mathrm{~m}$ thick and consists of angular carbonate and silicate melt rock fragments, with diameters up to several $\mathrm{cm}$ (Figs. 2b, e, 3c), displaying weak inverse grading. The fragments are set in a green matrix composed of sparitic calcite and subordinate amounts of clay minerals (Fig. 3c). Calcite grain boundaries are interlobate and calcite grain size decreases toward silicate fragment boundaries (Fig. 4d). Calcite displays equigranular (foam) texture (Fig. 4f), which is most pronounced away from silicate minerals and in places is reminiscent of viscous flow (Fig. 3c). Equigranular calcite is also evident in carbonate fragments. Silicate impact melt rock fragments display a mottled texture (Fig. 3c), include vesicles filled with quartz and calcite, with some showing spherulitic phyllosilicate fans and microcrystralline feldspar, akin to the petrographic characteristics of unit 3B (Fig. 3e). Viscous flow in melt rock fragments is evident by the shape-preferred alignment of angular fragments, xenocrysts, vesicles and feldspar phenocrysts.

Unit $2 \mathrm{C}-1$ is $2.72 \mathrm{~m}$ thick and replete with greenish, mostly angular fragments, $\sim 0.5 \mathrm{~cm}$ in diameter, embedded in a dark-brown, fragmented carbonate matrix (Figs. 2b, d, 3b). Fragments consist of target rock, carbonate and silicate melt rock, collectively showing resorbed margins and sporadically spherulitic inclusions of devitrified glass. Devitrification of fragments increases with depth and may affect entire fragments at the base of unit $2 \mathrm{C}-1$. Matrix grains vary in size and are subrounded (Fig. 4g), with a modal size distribution ranging from microcrystalline to $30 \mu \mathrm{m}$. Angularity and size of the matrix grains increase toward the centre of the unit. Compared to the units below, there are less opaque minerals in the matrix in unit 2C-1, which features abundant horizontal pressure solution seams and strain shadows at lateral fragment boundaries (Fig. 4h). Elongate to spheroid vesicles and inclusions may be replaced with secondary quartz, carbonate and radially disposed phyllosilicates.

\section{Composition of silicate impact melt rock}

Based on chemical analysis and the nomenclature for volcanic rocks proposed by LeBas et al. (1986), unit 3B impact 

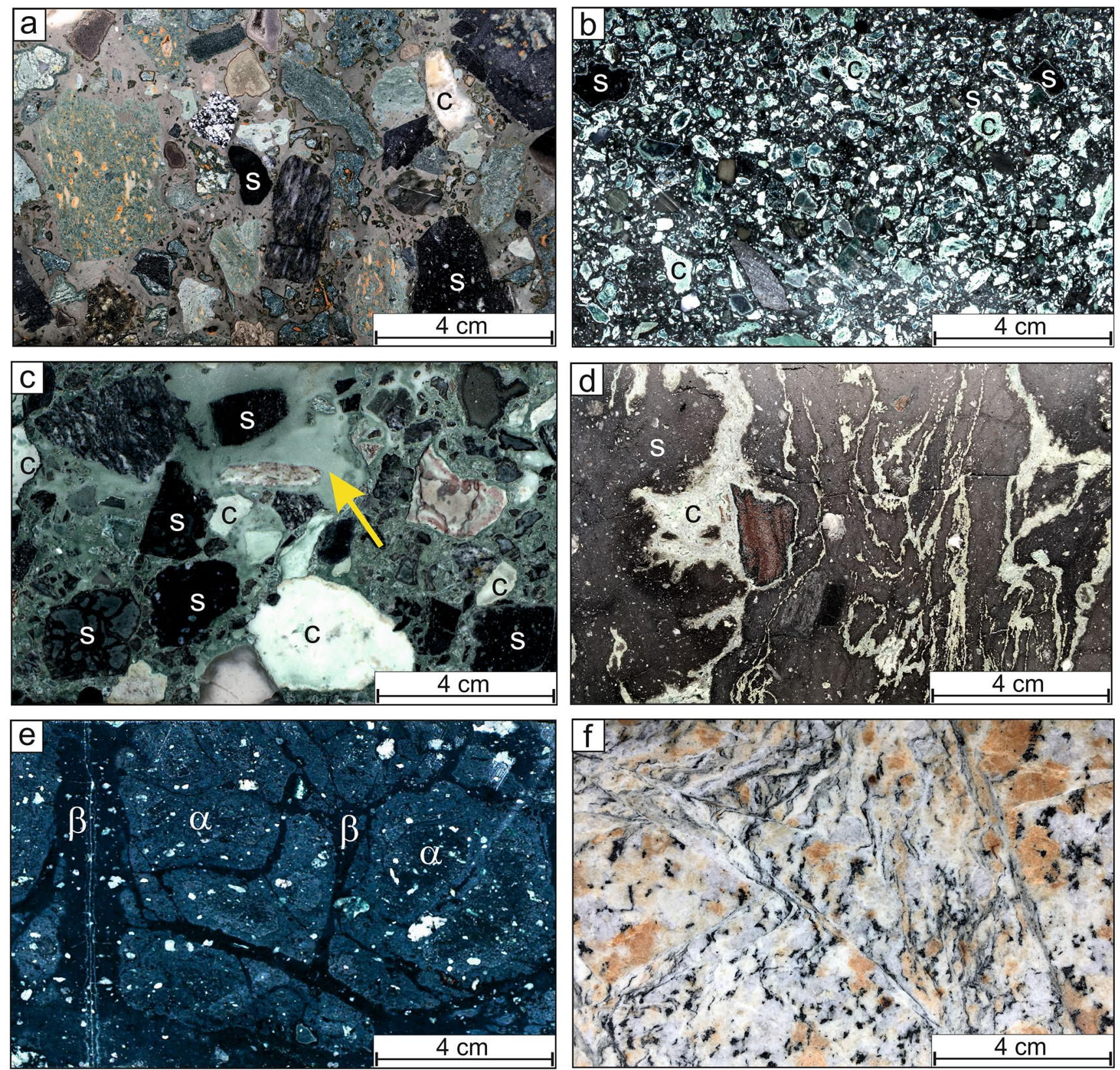

Fig. 3 Half-core impactite images of drill core M0077. $s$ silicate impact melt rock, $c$ carbonate mineral, $\alpha$ and $\beta$ denote different silicate melt rock phases. a Unit $2 \mathrm{~B}$ suevite characterized by polymict breccia fragments in brown carbonate matrix. b Unit 2C-1 impact melt rock breccia showing fragments of target rock, black and green silicate melt rocks in a dark carbonate matrix. Note resorbed fragment margins. c Unit 2C-2 impact melt rock breccia consisting of angular

melt rock has a trachyandesitic composition (silicate phase $\alpha: \mathrm{SiO}_{2}=59.39 \mathrm{wt} \%$ and $\mathrm{Na}_{2} \mathrm{O}+\mathrm{K}_{2} \mathrm{O}=6.44 \mathrm{wt} \%$, silicate phase $\beta: \mathrm{SiO}_{2}=61.33 \mathrm{wt} \%$ and $\mathrm{Na}_{2} \mathrm{O}+\mathrm{K}_{2} \mathrm{O}=7.28 \mathrm{wt} \%$ ), and unit $3 \mathrm{~A}$ melt rock has trachyte composition $\left(\mathrm{SiO}_{2}=61.29\right.$ wt $\%$ and $\mathrm{Na}_{2} \mathrm{O}+\mathrm{K}_{2} \mathrm{O}=11.27 \mathrm{wt} \%$ ). The $\mathrm{SiO}_{2}$-content of both units is similar to that obtained in previous analyses of Chicxulub impact melt rock (Table 2). The FeO content carbonate and silicate melt rock fragments set in a matrix composed of sparitic calcite. Arrow points at flow-textured equigranular calcite schlieren. d Unit 3A impact melt rock showing convoluted layers of black and green silicate melt rock phases. e Unit 3B impact melt rock displaying mottled texture with jigsaw geometry of hydrothermally altered fractures. f Unit 4 deformed and shocked target rock granitoid

$(\sim 1.1-2.4 \mathrm{wt} \%)$ and the $\mathrm{MgO}$ content $(\sim 0.2-1.0 \mathrm{wt} \%)$, however, are lower, and $\mathrm{Al}_{2} \mathrm{O}_{3}(\sim 23.7-18.0 \mathrm{wt} \%)$ is higher, than respective oxides in previous analyses (Table 1). The $\mathrm{Na}_{2} \mathrm{O}$ content $(\sim 4.6-5.2 \mathrm{wt} \%)$ is slightly elevated compared to previous data. $\mathrm{K}_{2} \mathrm{O}(\sim 1.4-2.7 \mathrm{wt} \%)$ and $\mathrm{CaO}(\sim 5.9-6.9$ $\mathrm{wt} \%)$ in unit $3 \mathrm{~B}$ melt rock are similar to respective oxides in impact melt rocks from the $\mathrm{C} 1$ and $\mathrm{Y} 6$ (unit N17) drill 

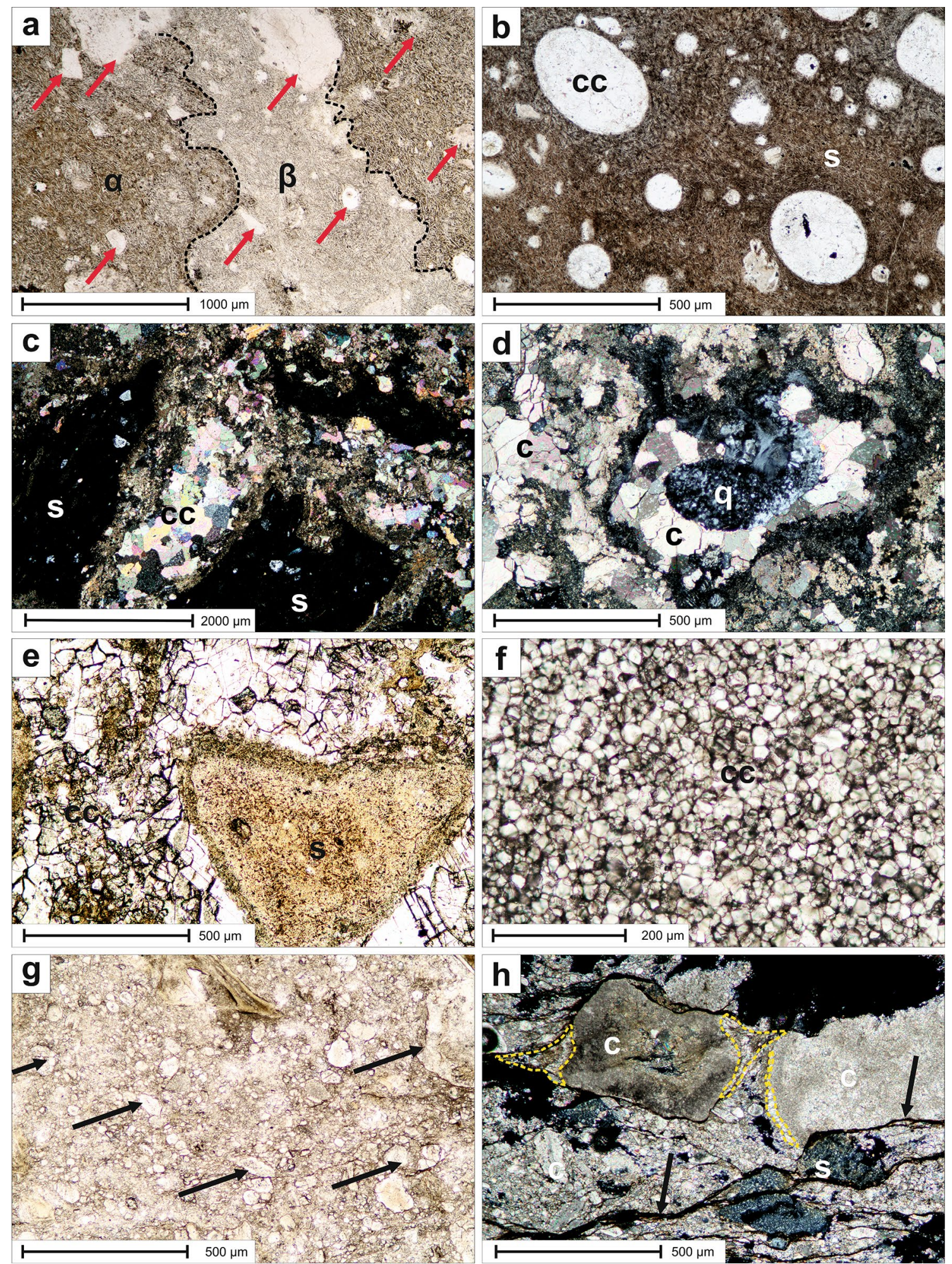

cores (Table 1). By contrast, the $\mathrm{K}_{2} \mathrm{O}$ content $(\sim 6.0 \mathrm{wt} \%)$ of unit $3 \mathrm{~A}$ is rather high, whereas the $\mathrm{CaO}$ content $(\sim 3.2 \mathrm{wt} \%)$ is low compared to all previous studies. Feldspar in unit $3 \mathrm{~B}$ has andesine composition in silicate phases $\alpha\left(\mathrm{An}_{40-47}\right.$ $\left.\mathrm{Ab}_{40-56} \mathrm{Or}_{2-14}, n=9\right)$ and $\beta\left(\mathrm{An}_{37-49} \mathrm{Ab}_{47-49} \mathrm{Or}_{4-16}, n=6\right)$ and anorthoclase to sanidine composition in unit $3 \mathrm{~A}\left(\mathrm{An}_{9-27}\right.$ $\left.\mathrm{Ab}_{36-53} \mathrm{Or}_{24-55}, n=13\right)$. Overall, the chemical composition of the black silicate melt rock phase matches those obtained from impact melt rock at other drill sites of the Chicxulub impact structure (Claeys et al. 2003 and references listed in 
४Fig. 4 Photomicrographs of impact melt rock. $c$ carbonate mineral, $c c$ calcite, $s$ silicate, $q$ quartz, $\alpha$ and $\beta$ denote different silicate melt rock phases. a Unit $3 \mathrm{~B}$ aphanitic matrix showing two silicate phases, labelled $\alpha$ and $\beta$. Arrows point at target-rock xenocrysts (planepolarized light). b Unit 3B aphanitic alkali feldspar matrix hosting elongate vesicles, filled with sparitic calcite (plane-polarized light). c Unit 3A matrix displaying the silicate melt rock phase and the carbonate-bearing phase with sparitic calcite and marginal clay minerals (cross-polarized light). d Unit $3 \mathrm{~A}$ carbonate-bearing phase consisting of lobate calcite and enveloping elliptical polycrystalline quartz aggregate (cross-polarized light). e Unit 2C-2 calcite matrix hosting angular silicate melt rock fragment (plane-polarized light). f Unit 2C-2 equigranular calcite matrix (cross-polarized light). g Unit 2C-1 impact melt rock breccia with fragmented calcite matrix (plane-polarized light). h Unit 2C-1 impact melt rock breccia displaying pressure solution seams (brown) and strain shadows next to larger carbonate fragments (dotted lines) (cross-polarized light)

Table 2). This result agrees with the interpretation that this melt rock phase is part of a relatively homogeneous impact melt sheet in terms of composition.

\section{Discussion}

\section{Deformation mechanisms of the impact melt rock sequence}

The petrographically uniform, black silicate melt rock phase of unit 3B forms the base of the impact melt rock sequence; whereas, two phases, made up of the black silicate melt rock and the green silicate phase comprised of calcite and clay minerals, make up the remainder of the sequence, i.e., units 3A, 2C-1 and 2C-2 (Fig. 2b). The aphanitic and mottled texture of the unit $3 \mathrm{~B}$ impact melt rock indicates rapid cooling, and the jigsaw fracture geometry points to subsequent (auto-)brecciation of a solidifying melt.

The convoluted schlieren pattern of unit 3A melt rock is indicative of viscous flow of the two phases prior to their solidification. Further evidence for viscous flow includes the presence of centimetre-scale folds of phase boundaries (Figs. 2f, 3d), the shape-preferred orientation of xenocrysts and elongate calcite- and quartz-filled vesicles (Fig. 4d), and the cusp-and-lobe geometry of the melt rock phases (Figs. 2b, 3d). The latter indicates that the black silicate phase, which also forms elongate and pulled-apart fragments within the green phase, was mechanically more competent during flow than the green phase. These characteristics point to incomplete mixing of two compositionally different melt phases during cooling and solidification.

Units $2 \mathrm{C}-1$ and $2 \mathrm{C}-2$ are made up of the same melt rock phases as unit $3 \mathrm{~B}$. In units $2 \mathrm{C}-1$ and $2 \mathrm{C}-2$, however, the melt rock is brecciated (Fig. 3b, c). Overall, angularity of fragments and fragmentation intensity, evident by the fragment size, in the melt rock sequence increases from bottom to top. The aphanitic texture of the black silicate melt rock, gradational boundaries among units, and a decrease in viscous deformation along with an increase in fragmentation intensity toward the top of the sequence, point to deformation during rapid solidification, while being cooled from the top and the bottom.

\section{Origin of melt rock phases}

Disentangling the processes by which the melt rock sequence formed hinges on knowledge of the origin of the two phases and the individual subunits of the sequence. As noted earlier, chemical differentiation (e.g., Bowen 1928; Wilson 1993) is among the most common hypotheses accounting for compositionally different layers in silicate impact melt sheets (Grieve et al. 1991; Therriault et al. 2002; Latypov et al. 2019). This mechanism, however, requires slow cooling of thick (km-scale) impact melt sheets that solidify to coarse-grained impact melt rocks. Given the aphanitic texture of the silicate melt rock phase and a thickness of only $46.37 \mathrm{~m}$ (Fig. 2), it is not possible that chemical differentiation outpaced the obviously rapid solidification of the silicate melt phase. Moreover, the presence of both phases at the top (units $2 \mathrm{C}-2$ and $2 \mathrm{C}-1$ ), in contrast to a single melt rock phase at the bottom (unit 3B), of the sequence negates chemical differentiation, as the cause for the presence of the two phases. For the same reasons, separation of compositionally immiscible (silicate) melts, forming a magmatic emulsion, during cooling (Zieg and Marsh 2005) is unlikely. This mechanism requires the development of two cooling fronts, one at the top and one at the bottom of the melt sheet, both moving toward the melt sheet centre during cooling and leaving behind compositionally different melt rock phases. This, however, is not observed in the Site M0077 drill core.

Selective assimilation of target rock fragments in impact melt may generate compositionally different melt rock layers (Grieve 1975), notably if the density difference between melt and fragments cause the latter to accumulate at a particular level in the melt sheet (Golightly 1994). Evidence for rapid cooling of the black silicate melt rock, presence of tiny xenocrysts and target-rock fragments and overall low spatial density, but uniformly random distribution, of fragments in both melt rock phases renders this process of generating compositionally different impact melts unlikely.

Another mechanism to consider is that impact into a carbonate-evaporite sequence overlying granitoid basement rocks generated two physically and chemically different impact melt phases, one carbonate-rich and the other silicate-rich. As the green silicate phase consists chiefly of clay minerals and secondary calcite, it is unknown whether it formed from a carbonate melt. Moreover, it is uncertain, whether the two phases separated from an initially homogeneous impact melt, or resulted from incomplete homogenization of two immiscible phases to begin with, as suggested 

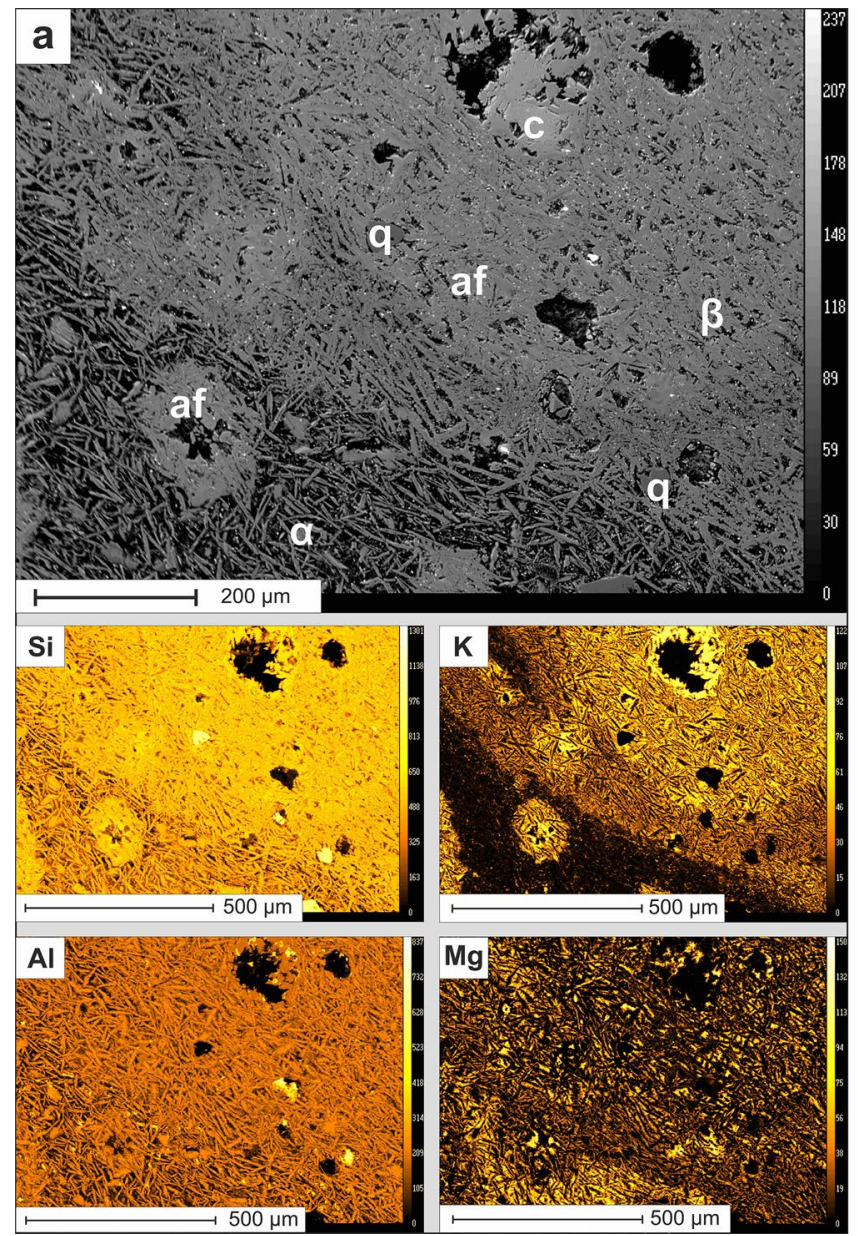

Fig. 5 Back-scattered electron (BSE) images and selected element maps of units 3A and 3B. $a d r$ andradite garnet, af alkali feldspar, $c$ carbonate mineral, $q$ quartz, a BSE image showing the two silicate phases, $\alpha$ and $\beta$. The element maps show high contents in $\mathrm{Si}, \mathrm{Fe}$ and $\mathrm{Al}$ as well as $\mathrm{Mg}$ in the feldspar interstices. Silicate phase $\beta$ is characterized by a high $\mathrm{K}$ content pointing to alkali feldspar as the domi-

by Graup (1999) and Osinski et al. (2008b, 2018) for other impact craters. Both scenarios would generate the observed fluidal textures of the immiscible phases on multiple scales (Figs. 2f, 3d, 6b), as well as inclusions and vesicles of one phase within the other (Fig. 4b, d). Regardless of which of the two scenarios is considered, evidence for immiscibility of the two phases is expected to be seen pervasively in the melt rock sequence. As unit 3B is devoid of the green silicate phase, neither of the two scenarios seem to account for an impact melt origin of this phase and, thus, calls for its allochthonous origin and admixing into the black silicate impact melt phase from the top.

Slivicki et al. (2019) considered the green phase to result from alteration of a finer-grained or glassy silicate-rich melt, with a chemical composition slightly different from the black silicate melt. If so, the two melt phases making up unit $3 \mathrm{~A}$ must have had nearly identical mechanical competency
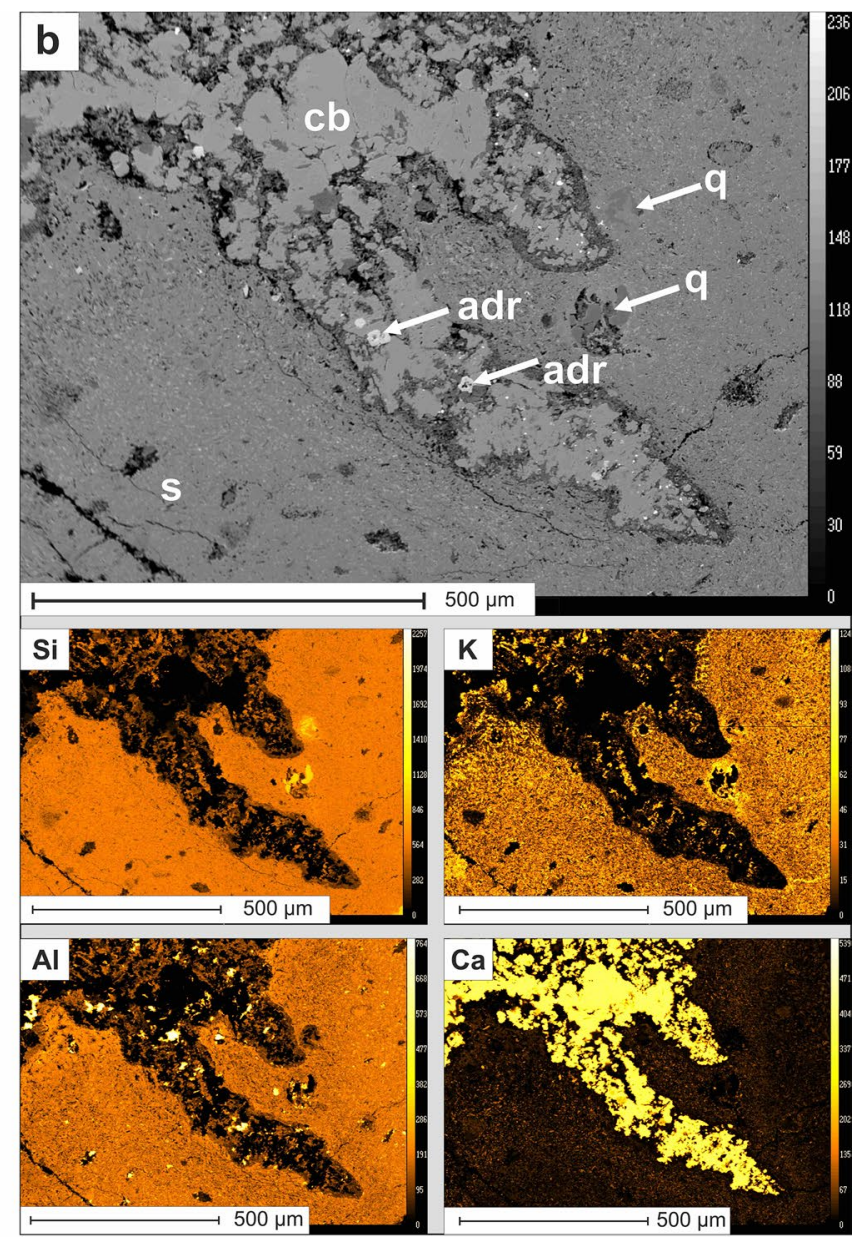

nant mineral phase. Silicate phase $\alpha$ hosts an alkali feldspar fragment, whereas silicate phase $\beta$ contains quartz fragments and a carbonate fragment. b BSE image showing unit 3A silicate melt rock and carbonate-bearing phases. Element maps indicate high contents in $\mathrm{Si}, \mathrm{K}$ and $\mathrm{Al}$ for the silicate phase, and high $\mathrm{Ca}$ content for the carbonate phase, which also hosts andradite garnet

during mingling, unless both phases differed substantially in temperature, which is not likely for initially superheated impact melts. Thus, evidence for a significant competency contrast of both phases during their mingling does not support the hypothesis that both phases were melts with similar composition. Considering that mingling in unit $3 \mathrm{~A}$ and brecciation in units $2 \mathrm{C}-2$ and $2 \mathrm{C}-1$, i.e., layer formation, occurred by the same deformation process, brecciation at the top of the impact melt sequence calls for considerable shear strains imparted to the top of the sequence.

Given the previous discussion, we suggest that mingling of the green and the black silicate phases occurred during deformation of the impact melt sequence and, at a time, when the base of the melt rock sequence, unit 3B, had solidified, or more likely, had been quenched by the underlying (cooler) granitoid target rock. This renders admixing of the green silicate phase to a late stage of, or closely following, 
the impact cratering process. The most plausible process transporting allochthonous material into the crater and putting it into contact with impact melt is by catastrophic influx of rock debris-laden seawater caused by ocean resurge, which has been widely reported for Chicxulub (Goto et al. 2004; Gulick et al. 2019; Osinski et al. 2020). We, therefore, attribute the presence of the green silicate phase and its distinct structural and chemical characteristics to processes related to MWI during ocean resurge (Fig. 6), which occurred 30-60 min after impact (Gulick et al. 2019).

\section{Melt rock formation}

Based on results of IODP-ICDP Expedition 364, the dynamic collapse model was recently confirmed for the formation of the Chicxulub peak-ring impact structure (Morgan et al. 2016; Riller et al. 2018; Rae et al. 2019; Collins et al. 2020). In this model (Fig. 6a-d), impact-generated shock compression and release generated massive amounts of superheated impact melt (Fig. 6a). Shock-wave induced crustal-scale excavation then produced a bowl-shaped transient cavity lined by impact melt (Fig. 6b). Subsequently, gravitational instability of the transient cavity caused inward slumping of the cavity wall while the crater centre was uplifted (Fig. 6c). Collapse and radial outward displacement of centrally uplifted material over inward-slumped cavity wall segments to create a peak ring was followed by (longterm) gravitational settling of the peak ring in the terminal phase of crater modification (Fig. 6d). During much of the cratering process, target rocks transiently behaved like a viscous fluid, but regained sufficient mechanical strength during crater modification to build and sustain the topographic peak ring (Riller et al. 2018). The most elevated portions of the peak ring rise some $400 \mathrm{~m}$ above the impact-melt and suevite-covered crater floor. Impact melt and suevite also blanket the flanks of the peak ring (Gulick et al. 2019).

We envisage the following scenario for the formation of the melt rock sequence (Fig. 6e-h). As early as the central uplift collapsed outward, target rock was thrust upward to form the peak ring (Riller et al. 2018; Gulick et al. 2019). These target rocks would have been draped by impact melt such that during outward collapse, impact melt was either transported piggyback on top of target rock or flowed outward. Local uplift of target rock forming topographic highs of the peak ring caused uplifted impact melt to drain from the highs, leaving only behind impact melt trapped in topographically elevated depressions. These portions of impact melt were cut off from melt exchange between the inner crater and the annular trough. Hence, melt ponds on top of peak ring highs started to cool under static conditions. The drilled impact melt rock studied here formed likely in a topographic depression. This setting accounts for the limited thickness of impact melt rock units 3 and $2 \mathrm{C}$, compared to that in the central part of the crater, and the lack of evidence for melt flow at the base of the impact melt rock, i.e. unit 3B.

Following peak-ring formation and initial deposition of impact ejecta (Fig. 6e), rock debris-laden seawater as a consequence of ocean resurge entered the crater and overrode the impact melt sheet (Fig. 6f). Based on geophysical imaging, a breach of the northeastern crater rim allowed the ingress of ocean water predominantly from this direction into the crater (Gulick et al. 2019). One-dimensional dam break modelling of the flooding of the crater indicates that the water level reached the top of the peak ring at about 30-60 min after impact (Gulick et al. 2019). Contact of the water-debris mixture with impact melt caused MWI including phreatomagmatic explosions (Grieve et al. 2010; Osinski et al. 2020) and mixed both phases, notably at the toe of the incoming mixture (Fig. 6f).

Due to the differences in density, temperature, viscosity and velocity, the water-debris mixture overriding the impact melt triggered Kelvin-Helmholtz instabilities (shearinduced mingling), and, subordinately, Rayleigh-Taylor instabilities (buoyancy-driven mingling), at their interface. As a consequence, shearing at the interface perturbed and, thus, mingled both (immiscible) phases, while phreatomagmatic explosions continued (Fig. 6f, g). Fluid perturbation entrained the less viscous, and likely less dense, seawater-debris mixture into the impact melt, evident by unit 3A. This process may have also introduced volatiles to the impact melt, which further decreased melt viscosity as a result (Lesher and Spera 1999), thus, enhancing the mechanical competency contrast between the solidifying impact melt and the water-rock mixture. At the same time, this mixture, likely forming an emulsion, quenched the top portions of the impact melt.

Continued phreatomagmatic explosions and shearing of the impact melt and the water-rock-mixture, quenched by seawater, left behind a peperitic impact melt breccia making up unit 2C-2 (Fig. 6h). Upon waning of these processes, finer-grained target rock and melt rock fragments-fragmented by phreatomagmatic explosions-along with stirred carbonate reacted chemically with the seawater, and formed the unit 2C-1 brecciated impact melt rock (Fig. 6h). Quenching of the breccia layers prevented their reworking during subsequent deposition of unit 2B suevite (Fig. 3a), evident by the well-defined, discordant contact between units $2 \mathrm{C}-1$ and 2B (Fig. 2b). Heating of the solidified melt rock breccia layers from the still hot impact melt below can account for identical inclinations of remanent magnetisation vectors in units $2 \mathrm{C}-1$ and $2 \mathrm{C}-2$ and underlying impact melt rocks, which is not observed for units $2 \mathrm{~B}$ and $2 \mathrm{~A}$ suevite (Gulick et al. 2019).

After cratering, the peak ring settled gravitationally, evident by horizontal extension of granitoid target rock in the solid-state (Riller et al. 2018). Due to its fine grain 

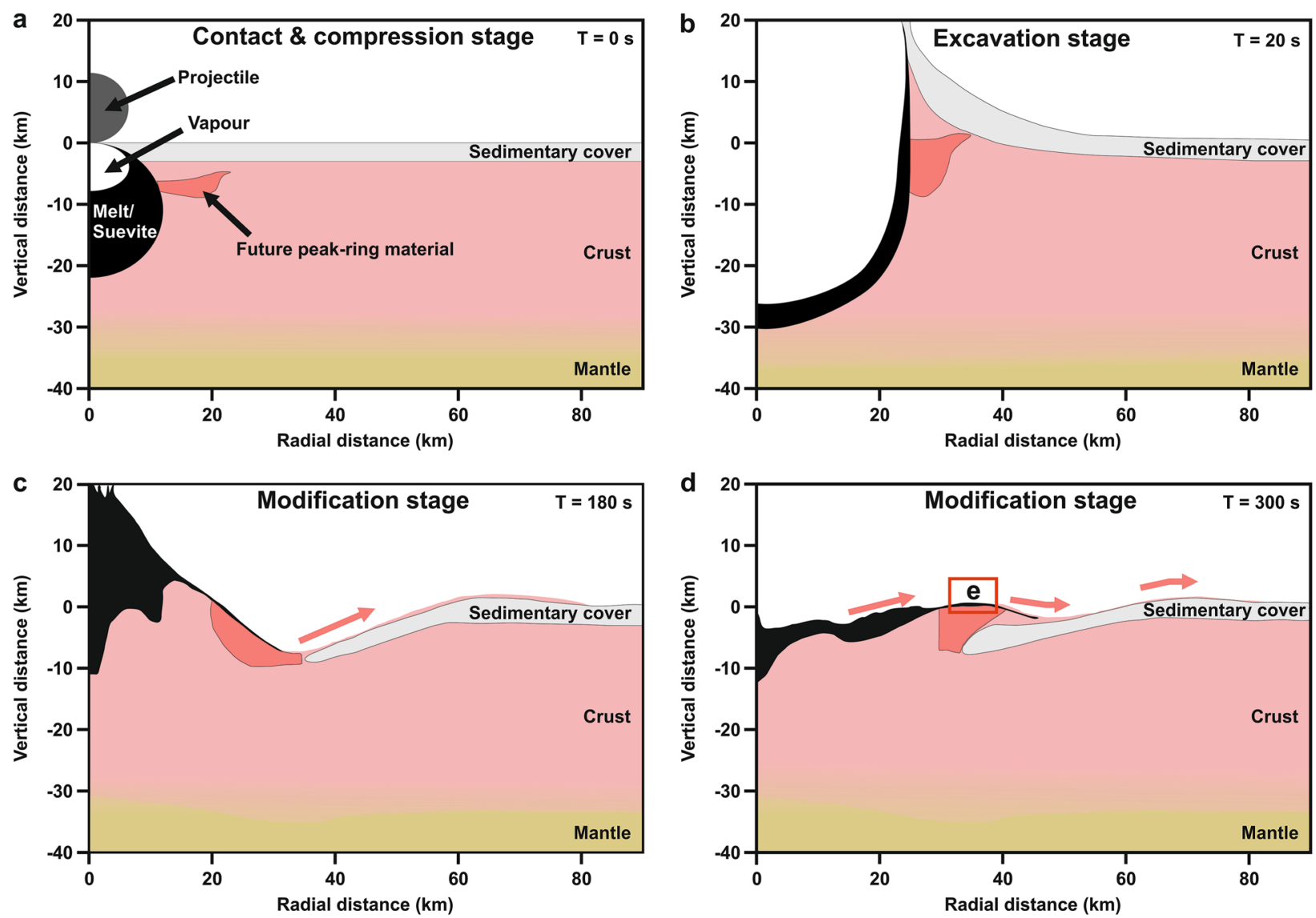

e

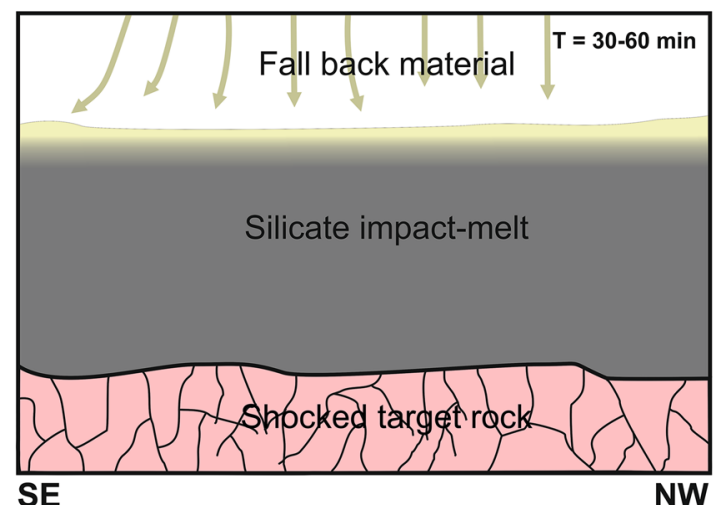

g

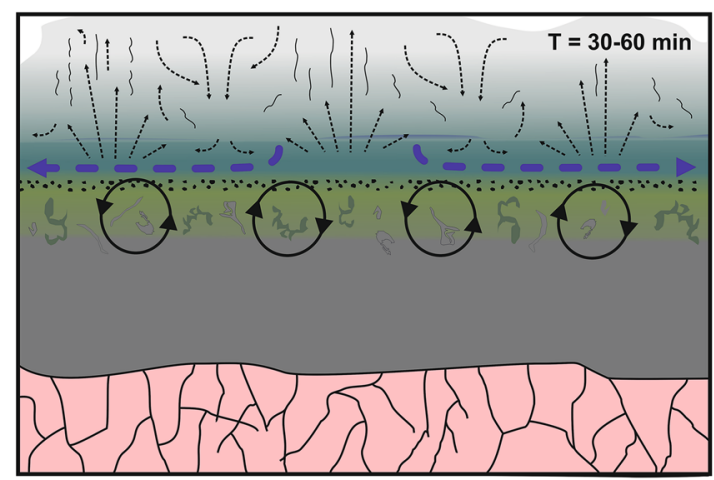

$f$

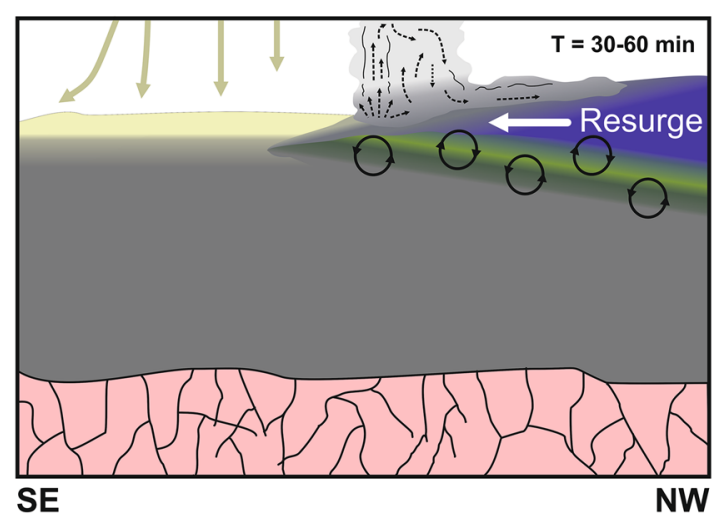

h

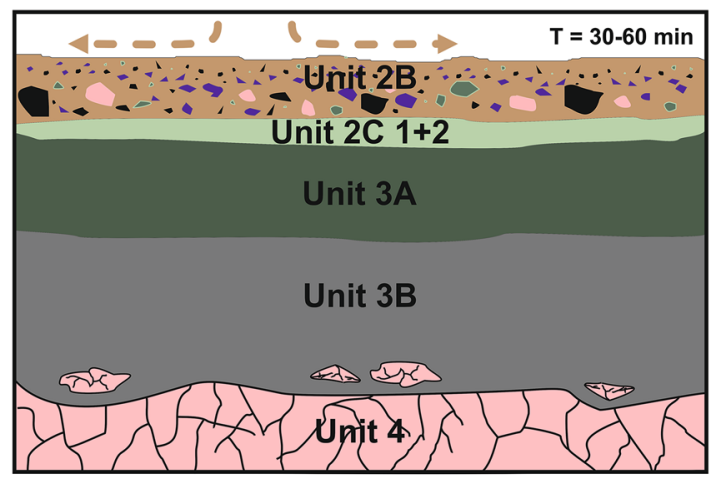


4Fig. 6 Schematic diagrams depicting major stages of the dynamic collapse model for peak-ring crater formation, based on numerical modelling (modified from Collins et al. 2002; Ivanov 2005; Kring et al. 2016; Morgan et al. 2016 and Rae et al. 2019) and formation of impact melt rock sequence. $\mathrm{T}$ denotes time after impact. a Contact and compression stage showing volumes of vaporized and shock-melted target rock. b Excavation stage showing transient cavity lined by impact melt. c Modification stage showing outward collapse of uplifted crater centre (red arrow) over slumped margin of transient cavity. (d) Modification stage showing formation of peak ring (red arrows) covered by impact melt. Rectangle marks position of $\mathbf{e}-\mathbf{h}$. e Silicate impact melt covers peak ring and receiving initial fall-back material (arrows). f Catastrophic influx of debris-laden seawater (white arrow) overrides silicate impact melt. Shearing at the melt-water interface causes Kelvin-Helmholtz instability and generates perturbations at the interface (circular arrows). These processes are accompanied by phreatomagmatic explosions at the toe of the incoming seawater-rock mixture (stippled arrows). g Melt perturbation continues and entrains coherent seawater-rock material into the silicate melt. Phreatomagmatic processes stir the phases and generate fragmented melt rocks on top of the perturbed layer. Seawater finally quenches the fragmented top of the impact melt sequence. $\mathbf{h}$ Subsequent deposition of suevite (unit 2B) on quenched impact melt breccia layers of units $2 \mathrm{C}-1$ and $2 \mathrm{C}-2$ (dashed arrows) overlying flowtextured unit $3 \mathrm{~A}$ and homogeneous impact melt rock of unit $3 \mathrm{~B}$

size, unit 2C-1 impact melt breccia formed a mechanically weak layer in the impactite stratigraphy and, therefore, preferably recorded evidence for long-term solid-state deformation. Layer-parallel pressure solution seams and lateral strain shadows at sizable fragments in the breccia (Fig. 4h) formed by horizontal extension and are, thus, in agreement with long-term gravitational settling of the peak ring. Moreover, it is conceivable that the mottled texture of unit $3 \mathrm{~B}$, the polygonal fractures of which were enhanced by hydrothermal alteration, was caused by this process as well. Specifically, elevated $\mathrm{Mg}$ contents characterizing the fractures (Fig. 5a) are due to breakdown of pyroxene with diopside cores and hedenbergite rims. Finally, we speculate that sparitic calcite and clay minerals in the green silicate phase replaced a hyaloclastic to peperitic phase (Hooten and Ort 2002), as a consequence of pervasive, post-cratering hydrothermal overprint of the impactites (Kring et al. 2020; Simpson et al. 2020). It cannot be excluded, however, that portions of equigranular calcite (Fig. 4f) are relics of a solidified carbonate melt, which may well have formed locally from carbonate fragments entrained in this phase.

\section{Summary and conclusion}

Petrographic, microstructural and chemical examination of the impact melt rock sequence of drill core from Site M0077 revealed the presence of two physically and chemically different impact silicate melt rock phases, a black and a green. The black silicate melt rock is trachyandesitic in composition and agrees with impact melt rock compositions from other sites in the Chicxulub impact structure. The green silicate phase consists chiefly of clay minerals and sparitic calcite, interpreted as secondary mineral phases that pervasively replaced a water-rock debris mixture under hydrothermal conditions. The base of the impact melt rock sequence is made up by the black silicate melt rock only; whereas, the middle and upper parts of the sequence display both phases, showing evidence for viscous mingling and brecciation, respectively.

We attribute deformation of the silicate melt phases to the contact of superheated silicate impact melt with a water-rock mixture brought about by ocean water overriding of the impact melt-covered peak ring of the impact structure upon ocean resurge. Notably, differences in density, temperature, viscosity and velocity of this mixture and impact melt triggered Kelvin-Helmholtz instability, and subordinately Rayleigh-Taylor instability, at their phase boundary. As a consequence, shearing at the boundary perturbed and, thus, mingled both (immiscible) phases. This process entrained the less dense and less viscous seawater-debris mixture into the solidifying silicate impact melt, causing phreatomagmatic explosions. Quenching of the upper-most impact melt rock breccias by the seawater prevented reworking of the breccias, upon subsequent deposition of suevite. Postsolidification deformation evident in the basal impact melt rock and the uppermost impact melt rock breccia attests to long-term gravitational settling of the peak ring. 
Table 2 Compositions (wt \%) of unit 3A and 3B silicate melt rocks and other impact melt rocks of the Chicxulub impact structure

\begin{tabular}{|c|c|c|c|c|c|c|c|}
\hline Drill site & M0077A & M0077A & M0077A & $\mathrm{C}-1$ & Y-6 & Y-6 & Y-6 \\
\hline Sample & $\begin{array}{l}\text { 364/77/A/95/ } \\
\mathrm{R} / 2 / \mathrm{W}\end{array}$ & $\begin{array}{l}\text { 364/77/A/95/ } \\
\mathrm{R} / 2 / \mathrm{W}\end{array}$ & $\begin{array}{l}\text { 364/77/A/88/ } \\
\mathrm{R} / 1 / \mathrm{W}\end{array}$ & & & & \\
\hline Unit & 3B $(\operatorname{sil} \alpha)$ & $3 \mathrm{~B}(\operatorname{sil} \beta)$ & Unit 3A & N10 & N17 & N19 & N17 \\
\hline $\begin{array}{l}\text { Depth of sample } \\
\text { (mbsf) }\end{array}$ & 745.24 & 745.24 & 723.5 & & & & 1295.5-1299 \\
\hline $\begin{array}{l}\text { Number of meas- } \\
\text { urements }\end{array}$ & $n=4$ & $n=15$ & $n=13$ & $n=1$ & $n=1$ & $n=7$ & $n=2$ \\
\hline $\mathrm{SiO}_{2}$ & $59.39 \pm 1.38$ & $61.33 \pm 4.59$ & $61.29 \pm 1.12$ & 64.4 & 62.30 & 58.50 & 61.85 \\
\hline $\mathrm{TiO}_{2}$ & $0.12 \pm 0.06$ & $0.12 \pm 0.05$ & $0.46 \pm 0.23$ & 0.53 & 0.50 & 0.44 & 0.40 \\
\hline $\mathrm{Al}_{2} \mathrm{O}_{3}$ & $23.66 \pm 0.58$ & $22.40 \pm 2.03$ & $17.97 \pm 1.06$ & 14.9 & 14.6 & 14.92 & 13.1 \\
\hline $\mathrm{FeO}$ & $1.07 \pm 0.19$ & $1.07 \pm 0.49$ & $2.44 \pm 0.81$ & 4.60 & 4.80 & 4.26 & 4.75 \\
\hline $\mathrm{MnO}$ & b.d & $0.01 \pm 0.02$ & $0.04 \pm 0.02$ & 0.09 & 0.10 & 0.10 & 0.10 \\
\hline $\mathrm{MgO}$ & $0.20 \pm 0.06$ & $0.33 \pm 0.31$ & $0.97 \pm 0.40$ & 2.76 & 2.90 & 2.87 & 3.15 \\
\hline $\mathrm{CaO}$ & $6.89 \pm 0.91$ & $5.87 \pm 2.69$ & $3.18 \pm 1.04$ & 5.50 & 8.80 & 10.76 & 10.35 \\
\hline $\mathrm{Na}_{2} \mathrm{O}$ & $5.03 \pm 0.82$ & $4.60 \pm 1.66$ & $5.23 \pm 0.57$ & 3.71 & 2.10 & 3.15 & 4.35 \\
\hline $\mathrm{K}_{2} \mathrm{O}$ & $1.41 \pm 0.62$ & $2.68 \pm 2.11$ & $6.04 \pm 1.23$ & 2.72 & 2.51 & 2.06 & 1.90 \\
\hline $\mathrm{BaO}$ & $0.04 \pm 0.04$ & $0.08 \pm 0.07$ & $0.10 \pm 0.07$ & n.a & n.a & n.a & n.a \\
\hline $\mathrm{P}_{2} \mathrm{O}_{5}$ & n.a & n.a & n.a & 0.11 & b.d & 0.11 & 0.09 \\
\hline $\mathrm{SO}_{2}$ & b.d & b.d & $0.01 \pm 0.01$ & 0.07 & $\mathrm{n} . \mathrm{a}$ & n.a & $\mathrm{n} . \mathrm{a}$ \\
\hline $\mathrm{SO}_{3}$ & n.a & n.a & n.a & $\mathrm{n} . \mathrm{a}$ & 0.07 & 0.10 & n.a \\
\hline Sum & $97.84 \pm 2.00$ & $98.5 \pm 1.13$ & $97.73 \pm 0.76$ & 99.82 & 98.7 & 97.03 & 100.04 \\
\hline Study & This work & This work & This work & $\begin{array}{l}\text { Schuraytz } \\
\text { et al. } \\
\text { (1994) }\end{array}$ & $\begin{array}{l}\text { Schuraytz } \\
\text { et al. } \\
\text { (1994) }\end{array}$ & $\begin{array}{l}\text { Schuraytz } \\
\text { et al. } \\
\text { (1994) }\end{array}$ & $\begin{array}{l}\text { Hildebrand et al. } \\
\text { (1991) }\end{array}$ \\
\hline
\end{tabular}

All $\mathrm{Fe}$ is indicated as $\mathrm{FeO}$

Acknowledgements Most insightful comments by the late H. Jay Melosh significantly improved the clarity of this contribution. K. Faak and P. Göllner are thanked for discussion. This work was funded by the German Science Foundation (Grants Ri 916/16-1, 2) awarded to U.R. S.P.S.G. was supported by NSF-OCE-1737351; this is University of Texas Institute for Geophysics Contribution No. 3772 and Center for Planetary Systems Habitability Contribution No. 0025. Contributions by D.A.K. were supported by the National Science Foundation (Grant OCE-1736826). LPI Contribution No. 2589. A.W. was supported by National Science Foundation grant OCE-1737087. The Chicxulub drilling expedition was funded by the European Consortium for Ocean Research Drilling (ECORD) and the IODP as Expedition 364, with co-funding from the ICDP. The Yucatán State Government and Universidad Nacional Autónoma de México (UNAM) provided logistical support. This research used samples and data provided by IODP. Samples can be requested at http://web.iodp.tamu.edu/sdrm. We are grateful for assistance from the staff of the IODP Core Repository in Bremen, Germany, during the Onshore Science Party. We thank the Editor-In-Chief, W.-Ch. Dullo, for handling the manuscript. The members of IODP-ICDP Expedition 364 Science Party: S. P. S. Gulick, Institute for Geophysics and Department of Geological Sciences, Jackson School of Geosciences, University of Texas at Austin, Austin, TX, USA. J. V. Morgan, Department of Earth Science and Engineering, Imperial College London, London, UK. T. J. Bralower, Department of Geosciences, Pennsylvania State University, State College, PA, USA. E. Chenot, Géosciences Montpellier, Université de Montpellier, Montpellier, France. G. L. Christeson, Institute for Geophysics, Jackson School of Geosciences, University of Texas at Austin, Austin, TX, USA, P. Claeys, Analytical, Environmental and GeoChemistry,
Vrije Universiteit Brussel, Brussels, Belgium. C. S. Cockell, Centre for Astrobiology, School of Physics and Astronomy, University of Edinburgh, Edinburgh, UK. M. J. L. Coolen, Department of Chemistry, WA Organic and Isotope Geochemistry Centre, Curtin University, Perth, Western Australia, Australia. L. Ferrière, Natural History Museum, Vienna, Austria. C. Gebhardt, Alfred Wegener Institute Helmholtz Centre of Polar and Marine Research, Bremerhaven, Germany. K. Goto, International Research Institute of Disaster Science, Tohoku University, Sendai, Japan, now at: Department of Earth and Planetary Science, University of Tokyo, Japan. S. Green, British Geological Survey, Edinburgh, UK. H. Jones, Department of Geosciences, Pennsylvania State University, University Park, PA, USA. D. A. Kring, Lunar and Planetary Institute, Houston, TX, USA. E. LeBer, School of Geography, Geology, and the Environment, University of Leicester, Leicester, UK. J. Lofi, Géosciences Montpellier, Université de Montpellier, Montpellier, France. C. M. Lowery, Institute for Geophysics, Jackson School of Geosciences, University of Texas at Austin, Austin, TX, USA. R. Ocampo-Torres, Groupe de Physico Chimie de l'Atmosphère, L'Institut de Chimie et Procédés pour l'Énergie, l'Environnement et la Santé (ICPEES), Université de Strasbourg, Strasbourg, France. L. Perez-Cruz, Instituto de Geofísica, Universidad Nacional Autónoma De México, Mexico, Mexico. A. E. Pickersgill, Argon Isotope Facility, Scottish Universities Environmental Research Centre, East Kilbride, UK. M. H. Poelchau, Institut für Geo- und Umweltnaturwissenschaften, Albert Ludwigs Universität, Freiburg, Germany. A. S. P. Rae, Institut für Geo- und Umweltnaturwissenschaften, Albert Ludwigs Universität, Freiburg, Germany. C. Rasmussen, Institute for Geophysics, Jackson School of Geosciences, University of Texas at Austin, Austin, TX, USA, Department of Geology and Geophysics, University of Utah, Salt 
Lake City, UT, USA. M. Rebolledo-Vieyra, Independent consultant, Cancun, Mexico. U. Riller, Institut für Geologie, Universität Hamburg, Hamburg, Germany. H. Sato, Dipartimento di Geoscienze, Università degli Studi di Padova, Padova, Italy. D. Schmitt, Department of Earth, Atmospheric, and Planetary Sciences, Purdue University, West Lafayette, IN, USA. J. Smit, Faculty of Earth and Life Sciences (FALW), Vrije Universiteit Amsterdam, Amsterdam, Netherlands. S. M. Tikoo, Earth and Planetary Sciences, Rutgers University, New Brunswick, NJ, USA, now at: Department of Geophysics, Stanford University, Stanford, California USA. N. Tomioka, Kochi Institute for Core Sample Research, Japan Agency for Marine Earth Science and Technology, Kochi, Japan. J. Urrutia-Fucugauchi, Instituto de Geofísica, Universidad Nacional Autónoma De México, Mexico, Mexico. M. T. Whalen, Department of Geosciences, University of Alaska Fairbanks, Fairbanks, AK, USA. A. Wittmann, Eyring Materials Center, Arizona State University, Tempe, AZ, USA. L. Xiao, School of Earth Sciences, Planetary Science Institute, China University of Geosciences, Wuhan, China. K. E. Yamaguchi, Department of Chemistry, Toho University, Chiba, Japan, now at: Disaster Prevention Research Institute, Kyoto University, Kyoto, Japan.

Funding Open Access funding enabled and organized by Projekt DEAL. This work was supported by the German Science Foundation (Grants Ri 916/16-1,2) and the National Science Foundation (Grants OCE-1737351, OCE-1736826 and OCE-1737087).

Availability of data and material Samples can be requested at http:// web.iodp.tamu.edu/sdrm.

Code availability Not applicable.

\section{Declarations}

Conflict of interest The authors declare no competing interests.

Open Access This article is licensed under a Creative Commons Attribution 4.0 International License, which permits use, sharing, adaptation, distribution and reproduction in any medium or format, as long as you give appropriate credit to the original author(s) and the source, provide a link to the Creative Commons licence, and indicate if changes were made. The images or other third party material in this article are included in the article's Creative Commons licence, unless indicated otherwise in a credit line to the material. If material is not included in the article's Creative Commons licence and your intended use is not permitted by statutory regulation or exceeds the permitted use, you will need to obtain permission directly from the copyright holder. To view a copy of this licence, visit http://creativecommons.org/licenses/by/4.0/.

\section{References}

Alvarez LW, Alvarez W, Asaro F, Michel HV (1980) Extraterrestrial cause for the cretaceous-tertiary extinction. Science 208:10951108. https://doi.org/10.1126/science.208.4448.1095

Anders D, Osinski GR, Grieve RAF, Brillinger DTM (2015) The basal Onaping intrusion in the north range: roof rocks of the Sudbury igneous complex. Meteoritics Planet Sci 50:1577-1594. https:// doi.org/10.1111/maps.12497

Barton PJ, Grieve RAF, Morgan JV, Surendra AT, Vermeesch PM, Christeson GL, Gulick SPS, Warner MR (2010). Seismic images of Chicxulub impact melt sheet and comparison with the Sudbury structure. In: Reimold WU, Gibson RL (eds) Large meteorite impacts and planetary evolution IV, Geol Soc Am Spec Paper 465, pp 103-113. https://doi.org/10.1130/2010.2465(07)

Bowen NL (1928) The evolution of igneous rocks. In: Yoder HS Jr (ed) The evolution of the igneous rocks-fiftieth anniversary perspective. Princeton

Christeson GL, Gulick SPS, Morgan JV, Gebhardt C, Kring DA, Le Ber E, Lofi J, Nixon C, Poelchau M, Rae ASP, Rebolledo-Vieyra M, Riller U, Schmitt DR, Wittmann A, Bralower TJ, Chenot E, Claeys P, Cockell CS, Coolen MJL, Ferrière L, Green S, Goto K, Jones H, Lowery CM, Mellet C, Ocampo-Torres R, Perez-Cruz L, Pickersgill AE, Rasmussen C, Sato H, Smit J, Tikoo SM, Tomioka N, Urrutia-Fucugauchi J, Wahlen MT, Xiao L, Yamaguchi KE (2018) Extraordinary rocks from the peak ring of the Chicxulub impact crater: P-wave velocity, density, and porosity measurements from IODP/ICDP Expedition 364. Earth Planet Sci Lett 495:1-11. https://doi.org/10.1016/j.eps1.2018.05.013

Claeys P, Heuschkel S, Lounejeva-Baturina E, Sanchez-Rubio G, Stöffler D (2003) The suevite of drill hole Yucatàn 6 in the Chicxulub impact crater. Meteoritics Planet Sci 38:1299-1317. https://doi. org/10.1111/j.1945-5100.2003.tb00315.x

Collins GS, Melosh HJ, Morgan JV, Warner MR (2002) Hydrocode simulations of Chicxulub crater collapse and peak-ring formation. Icarus 157:24-33. https://doi.org/10.1006/icar.2002.6822

Collins GS, Morgan JV, Barton P, Christeson GL, Gulick SPS, UrrutiaFucugauchi J, Warner M, Wünnemann K (2008) Dynamic modeling suggests terrace zone asymmetry in the Chicxulub crater is caused by target heterogeneity. Earth Planet Sci Lett 270:221-230. https://doi.org/10.1016/j.eps1.2008.03.032

Collins GS, Patel N, Davison TM, Rae ASP, Morgan JV, Gulick SPS, IODP-ICDP Expedition 364 Science Party (2020) A steeplyinclined trajectory for the Chicxulub impact. Nat Commun 11:1480. https://doi.org/10.1038/s41467-020-15269-x

Dence MR (1971) Impact melts. J Geophys Res 76:5552-5565. https:// doi.org/10.1029/JB076i023p05552

Deutsch A, Grieve RAF, Avermann BML, Brockmeyer P, Buhl D, Lakomy R, Müller-Mohr V, Ostermann M, Stöffler D (1995) The sudbury structure (Ontario, Canada): a tectonically deformed multi-ring impact Basin. Geol Rundsch 84:697-709. https://doi. org/10.1007/BF00240561

Floran RJ, Simonds CH, Grieve RA, Phinney WC, Warner JL, Rhodes MJ, Jahn BM, Dence MR (1976) Petrology, structure and origin of the Manicouagan melt sheet, Quebec, Canada: a preliminary report. Geophys Res Lett 3:49-52. https://doi.org/10.1029/GL003 i002p00049

Floran RJ, Grieve RAF, Phinney WC, Warner JL, Simonds CH, Blanchard DP, Dence MR (1978) Manicouagan impact melt, Quebec, 1, stratigraphy, petrology, and chemistry. J Geophys Res 83:27372759. https://doi.org/10.1029/JB083iB06p02737

Golightly JP (1994) The Sudbury Igneous Complex as an impact melt: evolution and Ore genesis. In: Lightfoot PC, Naldrett AJ (eds) Proceedings of the Sudbury-Noril's k Symposium, Ontario Geological Survey, Special volume 5, pp 105-118

Goto K, Tada R, Tajika E, Bralower TJ, Hasegawa T, Matsui T (2004) Evidence for ocean water invasion into the Chicxulub crater at the Cretaceous/Tertiary boundary. Meteoritics Planet Sci 39:12331247. https://doi.org/10.1111/j.1945-5100.2004.tb01139.x

Graup G (1999) Carbonate-silicate liquid immiscibility upon impact melting: Ries Crater, Germany. Meteoritics Planet Sci 34:425498. https://doi.org/10.1111/j.1945-5100.1999.tb01351.x

Grieve RAF (1975) Petrology and chemistry of the impact melt at Mistastin Lake crater, Labrador. Geol Soc Am Bull 86:1617-1629. https://doi.org/10.1130/0016-7606(1975)86\%3c1617:PACOTI\% 3e2.0.CO;2

Grieve RAF, Cintala MJ (1992) An analysis of differential impact meltcrater scaling and implications for the terrestrial impact record. 
Meteoritics Planet Sci 27:526-538. https://doi.org/10.1111/j. 1945-5100.1992.tb01074.x

Grieve RAF, Therriault A (2000) Vredefort, Sudbury, Chicxulub: three of a kind? Ann Rev Earth Planet Sci 28:305-338. https://doi.org/ 10.1146/annurev.earth.28.1.305

Grieve RAF, Dence MR, Robertson PB (1976) The generation and distribution of impacts melts: implications for cratering processes. Symposium on Planetary Cratering Mechanics. Lunar Planet Sci Inst Contrib 259:40-42

Grieve RAF, Dence MR, Robertson PB (1977) Cratering processes: as interpreted from the occurrence of impact melts. In: Roddy DJ, Pepin RO, Merrill RB (eds) Impact and explosion cratering: planetary and terrestrial implications. Pergamon Press, New York, pp 791-814

Grieve RAF, Stöffler D, Deutsch A (1991) The Sudbury Structure: controversial or misunderstood? J Geophys Res 96:22753-22764. https://doi.org/10.1029/91JE02513

Grieve RAF, Cintala MJ, Therriault AM (2006) Large-scale impacts and the evolution of the Earth's crust: the early years. In: Reimold WU, Gibson RL (eds) Processes on the early earth: Geol. Soc. Am. Special Paper, 405, pp 23-31. https://doi.org/10.1130/2006. 2405(02)

Grieve RAF, Reimold WU, Morgan JV, Riller U, Pilkington M (2008) Observations and Interpretations at Vredefort, Sudbury and Chicxulub: towards a composite kinematic model of terrestrial impact basin formation. Meteoritics Planet Sci 43:855-882. https://doi.org/10.1111/j.1945-5100.2008.tb01086.x

Grieve RAF, Ames DE, Morgan JV, Artemieva N (2010) The evolution of the Onaping formation at the Sudbury impact structure. Meteoritics Planet Sci 45:759-782. https://doi.org/10.1111/j. 1945-5100.2010.01057.x

Gulick SPS, Barton PJ, Christeson GL, Morgan JV, McDonald M, Mendoza-Cervantes K, Pearson ZF, Surendra A, Urrutia-Fucugauchi J, Vermeesch PM, Warner MR (2008) Importance of pre-impact crustal structure for the asymmetry of the Chicxulub impact crater. Nat Geosci 1:131-135. https://doi.org/10.1038/ngeo103

Gulick SPS, Christeson GL, Barton PJ, Grieve RAF, Morgan JV, Urrutia-Fucugauchi J (2013) Geophysical characterization of the Chicxulub impact crater. Rev Geophys 51:31-52. https://doi.org/ 10.1002/rog.20007

Gulick SPS, Bralower T, Ormö J, Hall B, Grice K, Schaefer B, Lyons $\mathrm{S}$, Freeman KH, Morgan J, Artemieva N, Kaskes P, de Graaf S, Whalen M, Collins G, Tikoo SM, Verhagen C, Christeson GL, Claeys P, Coolen M, Goderis S, Goto K, Grieve RAF, McCall N, Osinski GR, Rae ASP, Riller U, Smit J, Vajda V, Wittmann A, Expedition 364 Scientists (2019) The first day of the cenozoic. Proc Nat Acad Sci USA 116:19342-19351. https://doi.org/10. 1073/pnas.1909479116

Hildebrand AR, Penfield GT, Kring DA, Pilkington M, CamargoZanoguera A, Jacobsen SB, Boynton WV (1991) Chicxulub crater: a possible cretaceous/tertiary boundary impact crater on the Yucatán Peninsula, Mexico. Geology 19:867-871. https://doi.org/ 10.1130/0091-7613(1991)019\%3c0867:CCAPCT\%3e2.3.CO;2

Hildebrand AR, Pilkington M, Ortiz-Aleman C, Chavez RE, UrrutiaFucugauchi J, Connors M, Graniel-Castro E, Camara-Zi A, Halpenny JF, Niehaus D (1998) Mapping Chicxulub crater structure with gravity and seismic reflection data. In: Grady MM, Hutchinson R, McCall GJH, Rothery DA (eds) Meteorites: flux with Time and Impact Effects. Geol. Soc. Spec. Pub. 140, pp 155-176. https://doi.org/10.1144/GSL.SP.1998.140.01.12

Hooten JR, Ort MH (2002) Peperite as a record of early-stage phreatomagmatic fragmentation process: an example from the Hopi Buttes volcanic field, Navajo Nation, Arizona, USA. J Volcanol Geotherm Res 114:95-106. https://doi.org/10.1016/S03770273(01)00282-7
Huber MS, Kovaleva E, Riller U (2020) Modeling the geochemical evolution of impact melts in terrestrial impact basins: Vredefort Granophyre Dikes and Sudbury Offset Dikes. Meteoritics Planet Sci 55:2320-2337. https://doi.org/10.1111/maps.13582

Ivanov BA (2005) Numerical modeling of the largest terrestrial meteorite craters. Sol Syst Res 39:381-409. https://doi.org/10.1007/ s11208-005-0051-0

Ivanov BA, Deutsch A (1999) Sudbury impact event: cratering mechanics and thermal history. In: Dressler BO, Sharpton, VL (eds) Large meteorite impacts and planetary evolution II, Geol Soc Am Spec Paper 339, pp 389-397. https://doi.org/10.1130/08137-2339-6.389

Kieffer SW, Simonds CH (1980) The role of volatiles and lithology in the impact cratering process. Rev Geophys Space Phys 18:143181. https://doi.org/10.1029/RG018i001p00143

Kring DA (1993) The Chicxulub impact event and possible causes of K/T boundary extinctions. In: Boaz D, Dornan M (eds) Proceedings of the first annual symposium of fossils of Arizona, Mesa, Arizona, USA, Mesa Southwest Museum and Southwest Paleontological Society, pp 63-79

Kring DA (1997) Composition of Earth's continental crust as inferred from the compositions of impact melt sheets: 28th Lunar and Planetary Science Conference 28, pp 763-764 (Abstract)

Kring DA, Boynton WV (1992) Petrogenesis of an augite-bearing melt rock in the Chicxulub structure and its relationship to K/T impact spherules in Haiti. Nature 358:141-144. https://doi.org/10.1038/ $358141 \mathrm{a} 0$

Kring DA, Kramer GY, Collins GS, Potter RWK, Chandnani M (2016) Peak-ring structure and kinematics from a multi-disciplinary study of the Schrödinger impact basin. Nat Commun 7:13161. https:// doi.org/10.1038/ncomms 13161

Kring DA, Tikoo SM, Schmieder M, Riller U, Rebolledo-Vieyra M, Simpson SL, Osinski GR, Gattacceca J, Wittmann A, Verhagen CM, Cockell CS, Coolen MJL, Longstaffe FJ, Gulick SPS, Morgan JV, Bralower TJ, Chenot E, Christeson GL, Claeys P, Ferrière L, Gebhardt C, Goto K, Green SL, Jones H, Lofi J, Lowery CM, Ocampo-Torres R, Perez-Cruz L, Pickersgill AE, Poelchau MH, Rae ASP, Rasmussen C, Sato H, Smit J, Tomioka N, UrrutiaFucugauchi J, Whalen MT, Xiao L, Yamaguchi KE (2020) Probing the hydrothermal system of the Chicxulub Crater. Sci Adv 6:eaaz3053. https://doi.org/10.1126/sciadv.aaz3053

Latypov R, Chistyakova S, Grieve RAF, Huhma H (2019) Evidence for igneous differentiation in Sudbury Igneous Complex and impactdriven evolution of terrestrial planet proto-crusts. Nat Commun 10:508. https://doi.org/10.1038/s41467-019-08467-9

Le Bas MJ, Le Maitre RW, Streckeisen A, Zanettin B (1986) A chemical classification of volcanic rocks based on the total alkali-silica diagram. J Petrol 27:745-750. https://doi.org/10.1093/petrology/ 27.3.745

Lesher CE, Spera FJ (1999) Thermodynamic and transport properties of silicate melts and magma. In: Houghton B, McNutt SR, Rymer H, Stix J, Sigurdsson H (eds) The Encyclopedia of volcanoes. Academic Press Elsevier, pp 113-141

Lightfoot PC, Keays RR, Morrison GC, Bite A, Farrell KP (1997) Geological and geochemical relationships between the contact sublayer, inclusions, and the Main Mass of the Sudbury Igneous Complex: a case study of the Whistle Mine Embayment. Econ Geol 92:647-673. https://doi.org/10.2113/gsecongeo.92.6.647

Lopez Ramos P (1975) Geological summary of the Yucatán Peninsula. In: Nairn AEM, Stehli FG (eds) The Gulf of Mexico and the Caribbean. Springer, pp 257-282. https://doi.org/10.1007/ 978-1-4684-8535-6_7

Masaitis VL, Naumov MV, Mashchak MS (2005) Original diameter and depth of erosion of the Popigai impact crater, Russia. In: Kenkmann T, Hörtz F, Deutsch A (eds) Large meteorite impacts III. 
Geol. Soc. Am Special Paper 384, pp 131-140. https://doi.org/10. 1130/0-8137-2384-1.131

Melosh HJ (1989) Impact cratering: a geologic process. Oxford University Press, New York, p 245

Meyer C, Jébrak M, Stöffler D, Riller U (2011) Lateral transport of suevite inferred from 3D shape fabric analysis: evidence from the Ries impact crater, Germany. Geol. Soc. Am Bull 123, pp 2312-2319 https://doi.org/10.1130/B30393.1

Morgan JV, Warner MR, Chicxulub Working Group (1997) Size and morphology of the Chicxulub impact crater. Nature 390:472-476. https://doi.org/10.1038/37291

Morgan JV, Warner MR, Collins GS, Melosh HJ, Christeson GL (2000) Peak-ring formation in large impact craters: geophysical constraints from Chicxulub. Earth Planet Sci Lett 183:347-354. https://doi.org/10.1016/S0012-821X(00)00307-1

Morgan JV, Warner MR, Collins GS, Grieve RAF, Christeson GL, Gulick SPS, Barton PJ (2011) Full waveform tomographic images of the peak ring at the Chicxulub impact crater. J Geophys Res 116:B06303. https://doi.org/10.1029/2010JB008015

Morgan JV, Gulick SPS, Bralower T, Chenot E, Christeson GL, Claeys P, Cockell CS, Collins GS, Coolen M, Ferrière L, Gebhardt C, Goto K, Jones H, Kring DA, Le Ber E, Lofi J, Long X, Lowery C, Mellet C, Ocampo-Torres R, Osinski GR, Perez-Cruz L, Pickersgill A, Poelchau M, Rae A, Rassmussen C, Rebolledo-Vieyra M, Riller U, Sato H, Schmitt D, Smit J, Tikoo-Schantz S, Tomioka N, Urrutia-Fucugauchi J, Whalen MT, Wittmann A, Yamaguchi K, Zylbermann W (2016) The formation of peak rings in large impact craters. Science 354:878-882. https://doi.org/10.1126/ science.aah6561

Morgan JV, Gulick SPS, Mellett CL, Green SL, and the Expedition 364 Scientists (2017) Chicxulub: Drilling the K-Pg Impact Crater. In: Proceedings of the International Ocean Discovery Program, 364: College Station, TX (International Ocean Discovery Program). https://doi.org/10.14379/iodp.proc.364.2017

Naldrett AJ, Hewins RH (1984) The main mass of the Sudbury Igneous Complex. In: Pye EG, Naldrett AJ, Giblin PE (eds) The geology and ore deposits of the Sudbury structure, Sudbury, Ontario, Canada, Ontario Geological Survey, Special Volume 1, pp 235-251

Onorato PIK, Uhlmann DR, Simonds CH (1978) The thermal history of the Manicouagan impact melt sheet, Quebec. J Geophys Res 83:1298-2789. https://doi.org/10.1029/JB083iB06p02789

Osinski GR, Spray JG, Lee P (2005) Impactites of the Haughton impact structure, Devon Island, Canadian High Arctic. Meteoritics Planet Sci 40:1789-1812. https://doi.org/10.1111/j.1945-5100.2005. tb00147.x

Osinski GR, Grieve RAF, Collins GS, Marion C, Sylvester P (2008a) The effect of target lithology on the products of impact melting. Meteoritics Planet Sci 43:1939-1954. https://doi.org/10.1111/j. 1945-5100.2008.tb00654.x

Osinski GR, Spray JG, Grieve RAF (2008b) Impact melting in sedimentary target rocks: an assessment. In: Evans KR, Horton JW, King DT, Morrow JR (eds) The sedimentary record of meteorite impacts. Geol Soc Am Spec Paper 437, pp 1-17. https://doi.org/ 10.1130/2008.2437(01)

Osinski GR, Grieve RAF, Chanou A, Sapers HM (2016) The "suevite" conundrum, Part 1: the Ries suevite and Sudbury Onaping Formation compared. Meteoritics Planet Sci 51:2316-2333. https://doi. org/10.1111/maps.12728

Osinski GR, Grieve RAF, Bleacher JE, Neish CD, Pilles EA, Tornabene LL (2018) Igneous rocks formed by hypervelocity impact. J Volcanol Geotherm Res 358:25-54. https://doi.org/10.1016/j. jvolgeores.2018.01.015

Osinski GR, Grieve RAF, Hill PJA, Simpson SL, Cockell C, Christeson GL, Ebert M, Gulick SPS, Melosh HJ, Riller U, Tikoo SM, Wittmann A (2020) Explosive interaction of impact melt and seawater following the Chicxulub impact event. Geology 48:108-112. https://doi.org/10.1130/G46783.1

Phinney WC, Simonds CH (1977) Dynamical implications of the petrology and distribution of impact melt rocks. In: Roddy DJ, Pepin RO, Merrill RB (eds) Impact and explosion cratering: planetary and terrestrial implications. Proceedings of the symposium on planetary cratering mechanics. Pergamon Press, New York, pp 771-790

Pierazzo E, Melosh JH (1999) Hydrocode modeling of Chicxulub as an oblique impact event. Earth Planet Sci Lett 165:163-176. https:// doi.org/10.1016/S0012-821X(98)00263-5

Pierazzo E, Vickery AM, Melosh HJ (1997) A reevaluation of impact melt production. Icarus 127:408-423. https://doi.org/10.1006/icar. 1997.5713

Rae ASP, Collins GS, Poelchau M, Riller U, Davison TM, Grieve RAF, Osinski GR, Morgan JV, IODP-ICDP Expedition 364 Scientists (2019) Stress-strain evolution during peak-ring formation: a case Study of the Chicxulub impact structure. J Geophys Res 124:396417. https://doi.org/10.1029/2018JE005821

Rebolledo-Vieyra M, Urrutia-Fucugauchi J (2004) Magnetostratigraphy of the impact breccias and post-impact carbonates from borehole Yaxcopoil-1, Chicxulub impact crater, Yucatán, Mexico. Meteoritics Planet Sci 39:821-829. https://doi.org/10.1111/j.1945-5100. 2004.tb00932.x

Renne PR, Deino AL, Hilgen FJ, Kuiper KF, Mark DF, Mitchell WS III, Morgan LE, Mundil R, Smit J (2013) Time Scale of critical events around the Cretaceous-Paleogene boundary. Science 339:684-687. https://doi.org/10.1126/science.1230492

Riller U, Poelchau MH, Rae ASP, Schulte FM, Collins GS, Melosh HJ, Grieve RAF, Morgan JV, Gulick SPS, Lofi J, Diaw A, McCall N, Kring DA, IODP-ICDP Expedition 364 Science Party (2018) Rock fluidization during peak-ring formation of large impact structures. Nature 562:511-518. https://doi.org/10.1038/ s41586-018-0607-z

Schulte P, Alegret L, Arenillas I, Arz JA, Barton PJ, Bown PR, Bralower TJ, Christeson GL, Claeys P, Cockell CS, Collins GS, Deutsch A, Goldin TJ, Goto K, Grajales-Nishimura JM, Grieve RAF, Gulick SPS, Johnson KR, Kiessling W, Koeberl C, Kring DA, MacLeod KG, Matsui T, Melosh JH, Montanari A, Morgan JV, Neal CR, Nichols DJ, Norris RD, Pierazzo E, Ravizza G, Rebolledo-Vieyra M, Reimold WU, Robin E, Salge T, Speijer RP, Sweet AR, Urrutia-Fucugauchi J, Vajda V, Wahlen MT, Willumsen PS (2010) The Chicxulub asteroid impact and mass extinction at the Cretaceous-Paleogene boundary. Science 327:1214-1218. https://doi.org/10.1126/science.1177265

Schuraytz BC, Sharpton VL, Marín LE (1994) Petrology of impactmelt rocks at the Chicxulub multiring basin, Yucatán, Mexico. Geology 22:868-872. https://doi.org/10.1130/0091-7613(1994) 022\%3c0868:POIMRA\%3e2.3.CO;2

Sharpton VL, Dalrymple GB, Marín LE, Graham R, Schuraytz BC, Urrutia-Fucugauchi J (1992) New links between the Chicxulub impact structure and the Cretaceous/Tertiary boundary. Nature 359:819-821. https://doi.org/10.1038/359819a0

Simpson SL, Osinski GR, Longstaffe FJ, Schmieder M, Kring DA (2020) Hydrothermal alteration associated with the Chicxulub impact crater upper peak-ring breccias. Earth Planet Sci Let 547:116425. https://doi.org/10.1016/j.eps1.2020.116425

Slivicki SJ, Schmieder M, Kring DA and the IODP-ICDP Expedition 364 Science Party (2019) Petrologic analysis of greenblack impact melt rock with a history of hydrothermal alteration at Chicxulub. 50th Lunar and Planetary Science Conference, Abstract No. 2132

Smit J, Hertogen J (1980) An extraterrestrial event at the CretaceousTertiary boundary. Nature 285:198-200. https://doi.org/10.1038/ $285198 \mathrm{a} 0$ 
Spray JG, Thompson LM, Biren MB, O'Connell-Cooper C (2010) The Manicouagan impact structure as a terrestrial analogue site for lunar and martian planetary science. Planet Space Sci 58:538551. https://doi.org/10.1016/j.pss.2009.09.010

Stöffler D, Grieve RAF (1994) Classification and nomenclature of impact metamorphic rocks: a proposal to the IUGS Subcommission on the Systematics of Metamorphic Rocks. Abstract of the Lunar and Planetary Science Conference 22, pp 1347-1348

Stöffler D, Grieve RAF (2007) Impactites. In: Fettes D, Desmons J (eds) Metamorphic rocks: a classification and glossary of terms, recommendations of the International Union of Geological Science. Cambridge University Press, pp 82-92

Stöffler D, Artemieva NA, Wünnemann K, Reimold WU, Jacob J, Hansen BK, Summerson IAT (2013) Ries crater and suevite revisted-observations and modelling part I: observations. Meteoritics Planet Sci 48:515-589. https://doi.org/10.1111/maps. 12086

Stöffler D, Hamann C, Metzler K (2018) Shock metamorphism of planetary silicate rocks and sediments: proposal for an updated classification system. Meteoritics Planet Sci 53:5-49. https://doi. org/10.1111/maps.12912
Swisher CC III, Grajales-Nishimura JM, Montanari A, Margolis SV, Claeys P, Alvarez W, Renne P, Cedillo-Pardo E, Maurrasse FJ-MR, Curtis GH, Smit J, McWilliams MO (1992) Coeval ${ }^{40} \mathrm{Ar} /{ }^{39} \mathrm{Ar}$ ages of 65.0 million years ago from Chicxulub crater melt rock and Cretaceous-Tertiary boundary tektites. Science 257:954-958. https://doi.org/10.1126/science.257.5072.954

Therriault AM, Fowler AD, Grieve RAF (2002) The Sudbury Igneous Complex: a differentiated impact melt sheet. Econ Geol 97:15211540. https://doi.org/10.2113/gsecongeo.97.7.1521

Vermeesch PM, Morgan JV (2004) Chicxulub central crater structure: initial results from physical property measurements and combined velocity and gravity modelling. Meteoritics Planet Sci 39:10191034. https://doi.org/10.1111/j.1945-5100.2004.tb01127.x

Vermeesch PM, Morgan JV (2008) Structural uplift beneath the Chicxulub impact structure. J Geophys Res 113:B07103. https://doi.org/ 10.1029/2007JB005393

Wilson M (1993) Magmatic differentiation. J Geol Soc Lond 150:611624. https://doi.org/10.1144/gsjgs.150.4.0611

Zieg MJ, Marsh BD (2005) The Sudbury Igneous Complex: viscous emulsion differentiation of a superheated impact melt sheet. Geol Soc Am Bull 117:1427-1450. https://doi.org/10.1130/B25579.1 